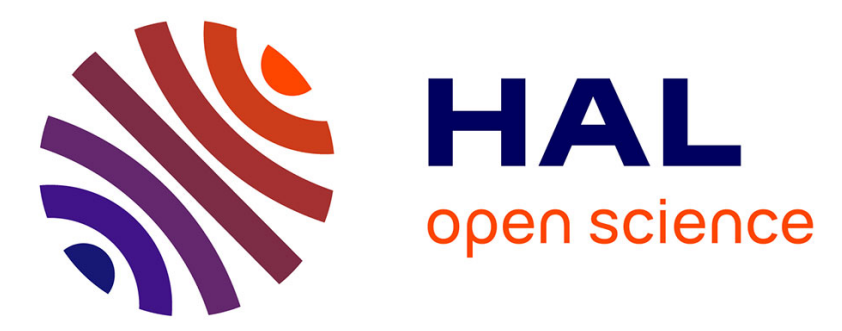

\title{
Sedimentology and depositional environment of the Late Eocene marine siliciclastic to evaporite transition in the Sivas Basin (Turkey)
}

\author{
Alexandre Pichat, Guilhem Hoareau, Michel Lopez, Jean-Paul Callot, \\ Jean-Claude Ringenbach
}

\section{To cite this version:}

Alexandre Pichat, Guilhem Hoareau, Michel Lopez, Jean-Paul Callot, Jean-Claude Ringenbach. Sedimentology and depositional environment of the Late Eocene marine siliciclastic to evaporite transition in the Sivas Basin (Turkey). Marine and Petroleum Geology, 2021, 131, 10.1016/j.marpetgeo.2021.105151 . hal-03252159

HAL Id: hal-03252159

https://hal-univ-pau.archives-ouvertes.fr/hal-03252159

Submitted on 7 Jun 2021

HAL is a multi-disciplinary open access archive for the deposit and dissemination of scientific research documents, whether they are published or not. The documents may come from teaching and research institutions in France or abroad, or from public or private research centers.
L'archive ouverte pluridisciplinaire HAL, est destinée au dépôt et à la diffusion de documents scientifiques de niveau recherche, publiés ou non, émanant des établissements d'enseignement et de recherche français ou étrangers, des laboratoires publics ou privés. 


\title{
Sedimentology and depositional environment of the Late Eocene marine siliciclastic to evaporite transition in the Sivas Basin (Turkey)
}

\author{
Alexandre Pichat ${ }^{\text {a,b, }}$, Guilhem Hoareau ${ }^{\text {a }}$, Michel Lopez ${ }^{c}$, Jean-Paul Callot ${ }^{\text {a }}$, \\ Jean-Claude Ringenbach ${ }^{\mathrm{b}}$ \\ a E2S-UPPA, Total, CNRS, Univ. Pau \& Pays Adour, Laboratoire des Fluides Complexes et leurs Réservoirs-IPRA, UMR5150, 64013, Pau, France \\ ${ }^{\mathrm{b}}$ Total SA, CSTJF, avenue Larribau, 64018, Pau, France \\ ${ }^{\mathrm{c}}$ Géoscience Montpellier, Université de Montpellier 2 Sciences et Technique, France
}

\section{A R T I C L E I N F O}

\section{Keywords:}

Evaporites

Gypsum

Anhydrite

Turbidites

Foreland

Sivas basin

\begin{abstract}
A B S T R A C T
The E-W oriented Sivas foreland basin in Turkey recorded a salinity crisis during the Late Eocene resulting in evaporite accumulations thick enough to trigger intense halokinesis during the Oligo-Miocene. The salinity crisis is studied thanks to three sedimentological sections crossing the transition from the last marine deposits (Bözbel Formation) to the overlying evaporitic facies (Tuzhisar Formation) preserved from halokinetic deformations. The top of the Bözbel Formation presents flood-generated hyperpycnites developed in pro-delta to delta front settings. In the central part of the basin, such facies become increasingly sediment-starved with azoic calcareous facies interlayered with organic-rich shales. Such facies are ultimately capped by thick accumulations of gypsiferous turbiditic lobe deposits. Southward, the foredeep was partly isolated from the central domain due to the propagation of an anticline. There, the basal siliciclastic turbidites become increasingly gypsum-rich and are capped by a 45 m-thick mass-transport deposit enclosing olistoliths of gypsum and of ophiolitic rocks. Such gravity collapse deposits evolve upward to the same gypsiferous turbiditic lobes observed northward. Both transitional facies record the progressive confinement of the basin from the sea, likely due to the northward propagation of the fold-and-thrust belt located farther south. The evaporites started to precipitate in piggy-back evaporitic basins, along the highs of the fold-and-thrust belt, before being reworked gravitationally in the foredeep to the north, producing the high to low density gypsum turbidites. Finally, from north to south, the reworked evaporites are extensively covered by a $>100 \mathrm{~m}$ thick, chaotic, prismatic gypsum mass likely resulting from the hydration of anhydrite grains left as a residual phase after the leaching of a significant amount of halite. The latter formed in a hypersaline marine-fed basin and have lately allowed mini-basin salt tectonics during Oligo-Miocene times.
\end{abstract}

\section{Introduction}

The Central Anatolian basins include up to 10 arc- and collisionrelated basins developed from the Late Cretaceous to the Pliocene during the northward subduction and closure of the northern Neotethys (Görür et al., 1998; Clark and Robertson, 2005; Nairn et al., 2012; Robertson et al., 2012). From the Middle Eocene to the Early Oligocene, all these basins recorded a coeval marine regression, characterized by the transition from carbonate platforms and turbiditic deposits to evaporitic facies and/or fluvial deposits (Görür et al., 1998; Cemen et al., 1999; Kaymakci, 2000; Clark and Robertson, 2005; Gündogan et al., 2005; Gürbüz and Gül, 2005; Huvaz, 2009; Booth et al., 2014; Keskin et al., 2017). The general shallowing upward tendency is usually attributed to the shortening and uplifting of the basins during the closure of the southern branch of the northern Neotethys, whereas the occurrence of evaporites would characterize the arid to semi-arid climate prevailing at that time (Görür et al., 1998; Cemen et al., 1999; Gündogan et al., 2005; Yilmaz and Yilmaz, 2006; Nairn et al., 2012). In the Tuzgölü, Çankırı and Sivas Basins, related salt accumulations were thick enough to allow halokinesis during the subsequent Oligo-Miocene sedimentation (Arikan, 1975; Ugurtas, 1975; Kaymakci et al., 2010; Legeay et al., 2020). The detailed facies of these evaporites, as well as of

\footnotetext{
* Corresponding author. E2S-UPPA, Total, CNRS, Univ. Pau \& Pays Adour, Laboratoire des Fluides Complexes et leurs Réservoirs-IPRA, UMR5150, 64013, Pau, France.

E-mail address: alexandre.pichat@gmail.com (A. Pichat).
} 
the preceding and succeeding deposits, has only been poorly described in the Central Anatolian basins (Tekin, 2001; Clark and Robertson, 2005; Gündogan et al., 2005). Consequently, the transition from the marine deposits to the thick evaporitic sequences still needs to be clarified.

The Sivas Basin, located in the northeast of the Anatolian Plateau, provides relevant outcrops to address this shortfall. Its marine evaporites, which precipitated during the Bartonian - Priabonian (Pichat et al., 2018), have only been described locally as the Tuzhisar Formation in the westernmost part of the basin, where gypsiferous accumulations are less than 100 m-thick (Gündogan et al., 2005). In the central part of the basin, the original thickness of the evaporitic succession remains unknown, but must have been quite thick enough to allowed the development of at least two generations of salt-withdrawal mini-basins (up to kilometer-thick) during the Oligo-Miocene (Ringenbach et al., 2013; Callot et al., 2014; Ribes et al., 2015, 2016, 2016; Kergaravat et al., 2016, 2017, 2017; Legeay et al., 2020; Pichat et al., 2019).

Through the detailed sedimentological study of three relevant outcrops located in the central part of the Sivas Basin, the present study intends to (i) document the facies and composition of sediments deposited during the transition from marine to evaporitic conditions during the Late Eocene, (ii) interpret the related depositional environments, and (iii) propose a facies model for the Tuzhisar evaporites. Observations and interpretations of the work may help understand comparable deposits accumulated at the same period over the Central Anatolian basins, or in similar geological settings elsewhere in the world.

\section{Geological setting}

The east-west trending Sivas foreland basin $(\sim 200 \mathrm{~km}$ by $\sim 50 \mathrm{~km})$ is located in the central part of the Anatolian Plateau in Turkey (Fig. 1 and Fig. 2). It lies at the junction between three major crustal blocks which are, from the north to the south, the Pontides, the Kirşehir Massif, and the Tauride-Anatolide block (Cater et al., 1991; Yilmaz and Yilmaz, 2006). Each block is separated by ophiolitic sutures resulting from the closure of the northern branches of the Neotethys Ocean during the late Cretaceous (Görür et al., 1998; Okay et al., 2006; Yilmaz and Yilmaz, 2006; Dilek and Sandvol, 2009; Rolland et al., 2010; Robertson et al., 2012).

Following obduction, the Sivas basin evolved as a supra-ophiolitic flexural basin associated with a northward propagating fold-and-trust belt (Cater et al., 1991; Guezou et al., 1996; Kergaravat et al., 2016; Legeay et al., 2019a). From the Maastrichtian to the Eocene, the foreland was marine and recorded (i) the development of carbonate

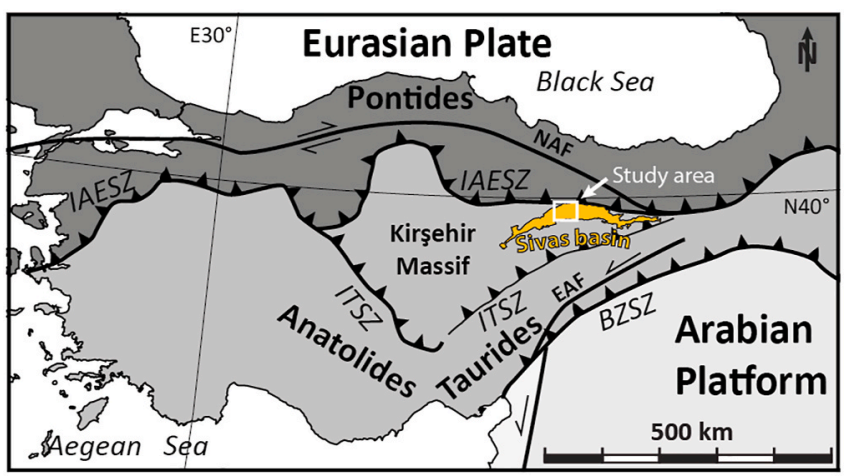

Fig. 1. Tectonic map of Eastern Mediterranean, with the main continental blocks (differentiated by shades of grey), major suture zones and the OligoMiocene Sivas basin deposits (after Ribes et al., 2015a modified from Okay et al., 2006). BZSZ: Bitlis-Zagros Suture Zone, EAF: East Anatolian Fault Zone, IAESZ: Izmir-Ankara-Erzingan Suture Zone, ITSZ: Inner-Tauride Suture Zone, NAF: North Anatolian Fault. platforms along the uplifting southern part of the basin, and (ii) the accumulation of calcareous to volcanoclastic turbiditic deposits in a NE-SW-oriented deep marine foredeep (Fig. 3; Kurtman, 1973; Cater et al., 1991; Aktimur et al., 1990; Cater et al., 1991; Altunsoy and Özçelik, 1998; Legeay et al., 2019b; Artan and Sestini, 1971; Kurtman, 1973; Cater et al., 1991; Artan and Sestini, 1971; Cater et al., 1991; Poisson et al., 2010; Legeay et al., 2019b). Paleocene, Cretaceous and ophiolitic rocks were uplifted and submitted to intense erosion sourcing turbiditic flows, that were deposited parallel to the basin axis toward the southwest (Artan and Sestini, 1971; Kurtman, 1973; Cater et al., 1991; Legeay et al., 2019b).

The Late Eocene records a transition from thin turbiditic deposits (Bözbel Formation) to evaporite deposits (Tuzhisar Formation) (Kurtman, 1973; Özçelik and Altunsoy, 1996; Tekin, 2001; Yilmaz and Yilmaz, 2006). In the central part of the Sivas Basin, the isotopic analysis of sulphates of the Tuzhisar Formation showed that the evaporites precipitated from seawater of Upper Lutetian to Priabonian age (Pichat et al., 2018), in accordance with sub-salt foraminifera assemblages and stratigraphical relationships (Poisson et al., 2011; Hakyemez et al., 2016). The sedimentological record of this turbidite to evaporite transition has only been studied by Gündogan et al. (2005) in the westernmost part of the Sivas Basin, near the Ortaköy village. There, shallow-water carbonates, marls and sandstones coeval to the Bözbel Formation gradually pass to $\sim 100 \mathrm{~m}$ of gypsiferous deposits interlayered with a 70 to $100 \mathrm{~m}$-thick, red clastic sequence. Gündogan et al. (2005) interpreted the gypsum deposits as having precipitated in a marine sabkha-lagoon setting. The top of the Tuzhisar Formation records conformable alluvial fan and channel deposits (Selimiye Formation), that mark the progressive continentalization of the basin.

In the central part of the basin, the original thickness of the Eocene evaporitic deposits remains unknown due to intense halokinesis, dissolution and erosion processes (Kergaravat et al., 2016, 2017). Nevertheless, the Tuzhisar formation was thick enough to allow the development of two generation of Oligocene and Miocene mini-basins separated by a salt canopy and filled by alluvial to shallow marine deposits (Kergaravat et al., 2016, 2017, 2017; Ribes et al., 2018; Legeay et al., 2020). Finally, the younger deposits of the basin include Pliocene and Quaternary alluvial to lacustrine facies (Fig. 3; Poisson et al., 1996).

\section{Data and methods}

The present study is based on 3 sedimentological sections, namely sections 1, 2, 3, logged over the central part of the Sivas Basin (Figs. 2 and 4). It was not possible to perform further sedimentological sections in the studied area due to the poor outcropping conditions. The studied sections start $20-80 \mathrm{~m}$ below the first occurrence of evaporitic facies, and they end where outcrop conditions prevented further measurements. Due to the presence of a south verging thrust, section 1 is duplicated on the field (Fig. $4 \mathrm{~A}$ and D). The duplicated interval is presented in supplementary data only. According to the cross-section restorations performed by Legeay (2017) and Legeay et al. (2020) in the studied area, sections 1 and 2 might have been distant of about 7-9 $\mathrm{km}$ during the Late Eocene.

The general reference facies scheme of Mutti et al. (2003) is used for the description of the detrital siliciclastic deposits in the Bözbel Formation. Clastic evaporite description follows the classification of Manzi et al. (2005). Detailed facies analyses were complemented by the petrographical analysis of 31 polished thin sections of sandstone, carbonate and gypsiferous facies.

\section{General stratigraphic succession of the Lutetian-Bartonian (Bözbel-Tuzhisar Formations)}

Fig. 5 displays a simplified version of the three sedimentary sections (the detailed logs are available in the supplementary material 1 to 4). In the three sections, the series start in the upper part of the Bözbel 


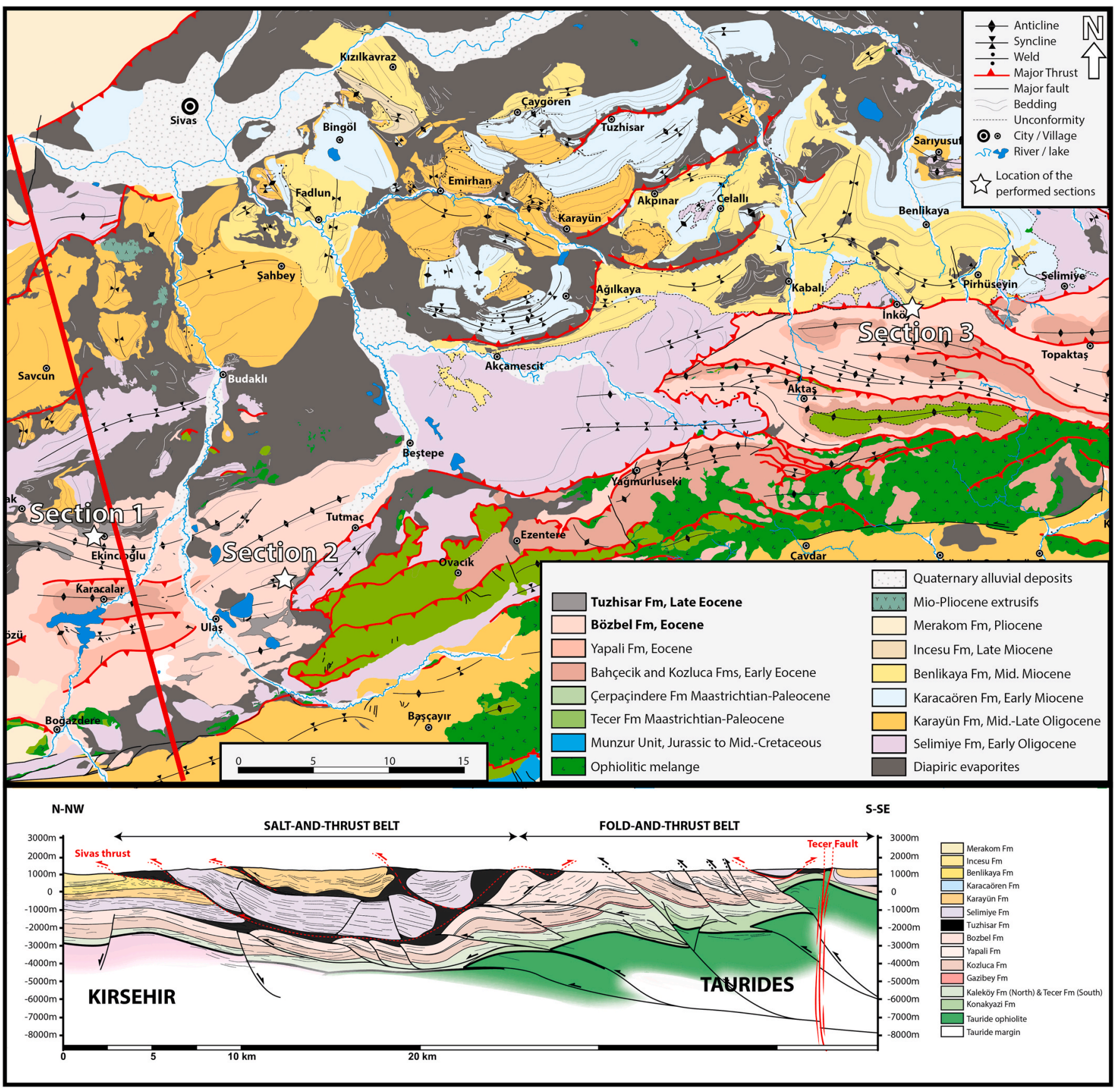

Fig. 2. Geological map of the studied area with location of studied sections (black and white stars) (after Legeay et al., 2019b) and a N-S cross-section based on seismic line interpretation (Legeay, 2017; Legeay et al., 2020).

Formation. The transition between the Bözbel and the Tuzhisar Formations is located where the first gypsum-rich deposits occur. The Bözbel Formation has been subdivided into 2 siliciclastic-rich facies associations (FA1 and 2) and 1 siliciclastic-poor facies associations (FA3, Fig. 5). The Tuzhisar Formation has been subdivided into 3 facies associations (FA4 to 6) (Fig. 5).

The lower part of the three sedimentary sections, corresponding to the upper Bözbel Formation, starts with sheet-like sandstone bodies (FA1 to 2, Fig. 6 A and B). In sections 1 and 3, the sand-rich deposits are grading upwards to muddy carbonates variably interlayered with organic-rich shales and sparse sandstone bodies (FA3, Fig. $6 \mathrm{~A}$ and C). Such deposits are absent in section 2 (Fig. 6 B). On the three sections, the series abruptly passes to gypsum-rich facies defining the Tuzhisar Formation (Fig. 6). In section 2 only, the Tuzhisar Formation starts with gypsum-rich sandstones capped by a $30 \mathrm{~m}$-thick chaotic and folded interval (FA4) (Fig. 6 B). Following gypsiferous facies, also observed in section 1 and 3 , are characterized by tabular gypsum beds with variable amounts of siliciclastics and clays, interlayered with carbonate to shale deposits (FA5, Fig. 6 B). Finally, both sections 1 and 2 end by stacked tabular gypsum beds interlayered with thin clay deposits and capped by a chaotic meshwork of coarse crystalline gypsum (FA6) of unknown total thickness (Fig. 6 D). This upper part of sections 1 and 2 could not be observed in section 3 due to poor outcrop conditions. The main sedimentary facies and facies associations are described in the following parts. 


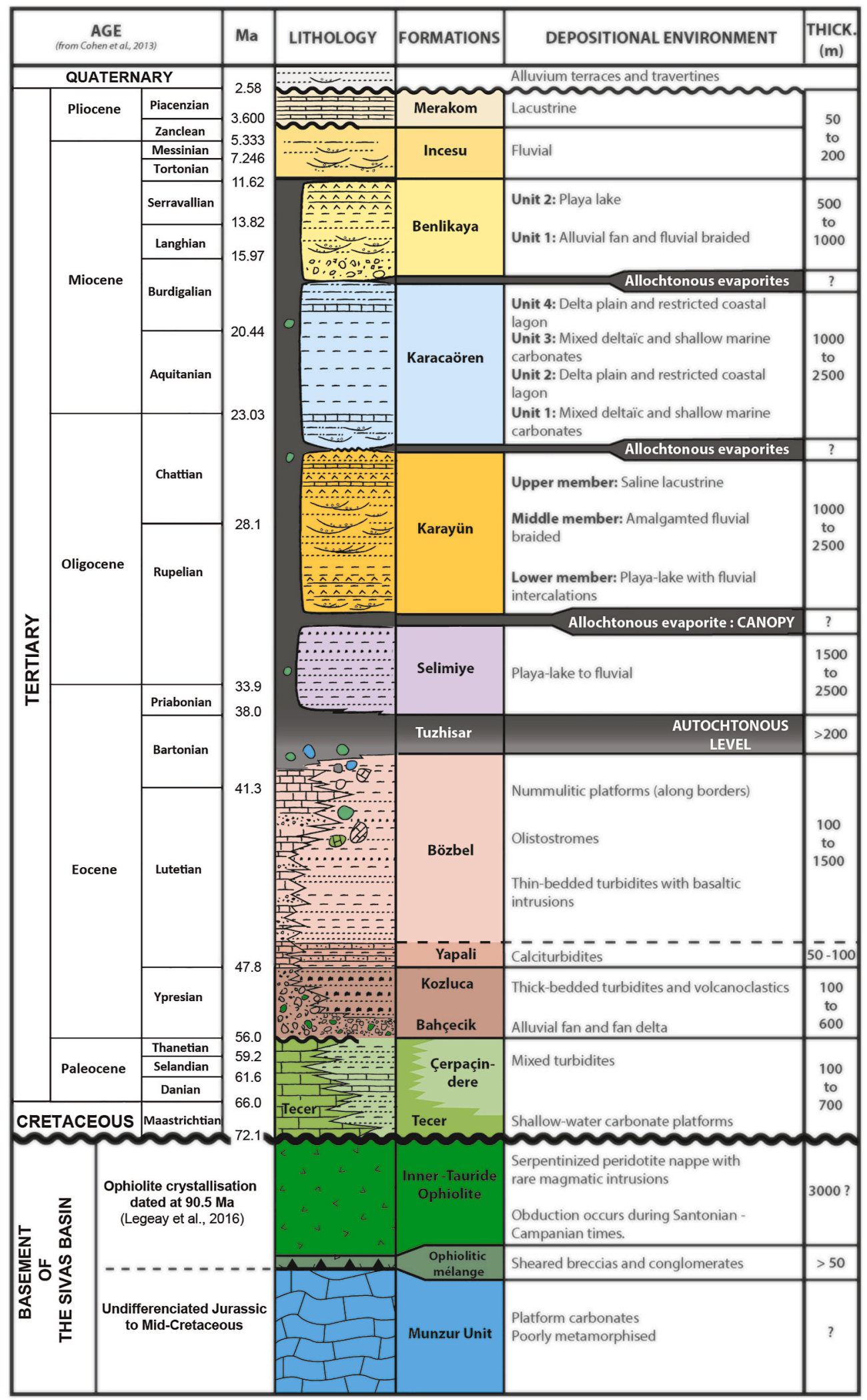

Fig. 3. Regional composite lithostratigraphic column of the central Sivas Basin, with average thickness of the various stratigraphic units (modified after Ribes, 2015; Kergaravat, 2016). 

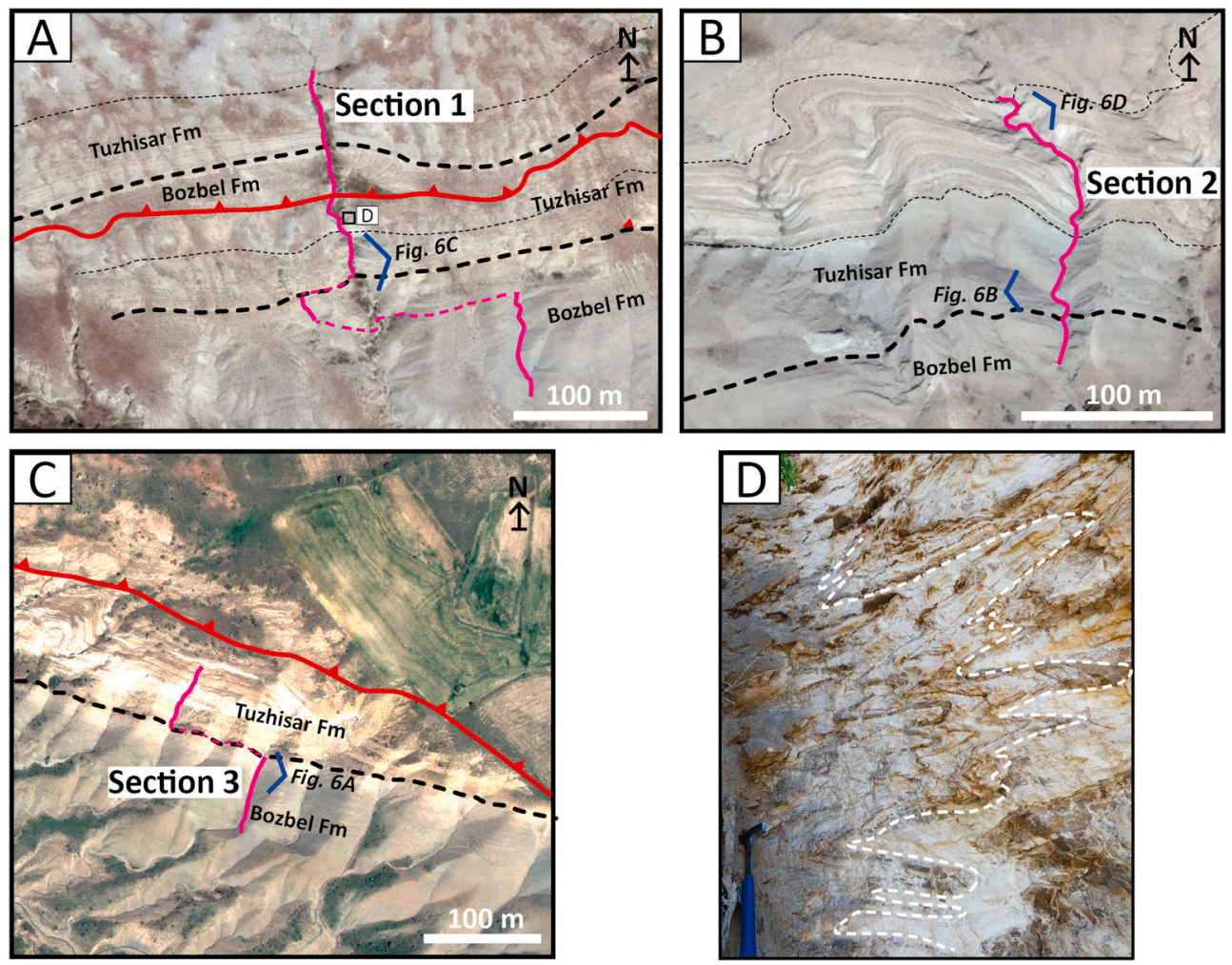

Fig. 4. A, B and C: Field location of the logged sections. See Fig. 2 for the location of the section on the geological map. D: Folded evaporites below a south verging thrust fault duplicating the Bözbel and Tuzhisar formations. See picture A for the location of the folds.

\section{Sedimentological description and depositional environments} of the Bözbel Formation (Lutetian): pre-evaporitic facies

\subsection{Facies analyses}

The facies analysis carried out in the upper part of the Bözbel Formation identifies three siliciclastic bed types (ST1 to 3, Fig. 7) related to turbidity currents and one facies related to chemical precipitation processes (SF1). The bed types are described following the nine facies types (F1 to F9) of Mutti et al. (2003), based on the down-current evolution of a waning and depletive turbidity current.

\subsubsection{ST1 to 3, siliciclastic turbidite bed types}

\section{a. ST1, thin medium-grained to silty sandstones}

These sandstone beds are a few centimeter-thick with a tabular shape and erosive base (Fig. $8 \mathrm{~A}, \mathrm{~B}$ ). They exhibit parallel to ripple laminations on top (F8 to F9 facies). Load-cast and water-escape structures are widespread (Fig. 8 B). The thickest sandstone beds grade into, or are capped by, parallel-laminated mudstones (Fig. 8 A). Small-scale slumps are also frequent.

\section{b. ST2, coarse normally to inversely graded coarse-grained sandstones}

These sandstone beds are up to $80 \mathrm{~cm}$-thick and may be subdivided in two main categories. The first category (ST2A) consists of tabular to poorly channelized beds displaying a fining upward trend from pebble conglomerates to fine-grained deposits represented by calcareous mudstones (Fig. $8 \mathrm{C}, \mathrm{D}$ ) with a sharp erosive base sometimes marked by flute casts (Fig. $8 \mathrm{D}$ ). The lower pebble conglomerate (F2 - F3 facies) is usually less than $20 \mathrm{~cm}$-thick; it quickly grades upward into even and parallel laminatae made of coarse-grained sandstone (Fig. $8 \mathrm{C}$ ), and trough cross-stratifications and/or ripples composed of medium-to fine- grained sandstone, sometime associated to megaripple stacking (F6-F7 analogous and F9 facies). The sandy body usually grades on its top to a mudstone including a variable siliciclastic fraction, which in places shows discrete parallel laminations and/or a wavy bedding (F9 facies, Fig. $8 \mathrm{C}, \mathrm{D}$ ). When the pebbly basal sandstone is absent, the mediumgrained sandstone division is locally lying on a coarsening upward mudstone to sandstone unit (Fig. $8 \mathrm{C}$, E). The main sandstone bodies can contain discrete plant debris and scarce horizontal burrows (Fig. 8 F). The second category (ST2 B) is only observed in section 2. It starts with a medium to coarse grained erosional sandstone but grades upward to a medium to fine sandstone displaying decimeter to centimeter wavelength hummocky cross-stratifications (Fig. 8 G, H).

\section{c. ST3, calcareous mudstones}

These beds are light-grey colored and up to $50 \mathrm{~cm}$-thick, with a variable siliciclastic content. They are both normally to inversely graded and show parallel laminations, cross-bedding and scouring structures or symmetrical to asymmetrical wavy bedding (F9 facies, Fig. 8 I and J).

These bed types are all interpreted as having been deposited by hyperpycnal flow in which reverse grading records the waxing flow stage of the hyperpycnal flow whereas normal grading rather marks the waning flow stage (Mulder et al., 2003; Mutti et al., 2003; Bourget et al., 2010). In bed type ST2a and b, the basal coarse to pebbly sandstone beds record basal dense flows whereas the overlying fining upward sandstone beds record the by-pass of more diluted and decelerating turbulent flow allowing the formation of tractive structures. In the type $2 b$, the hummocky-cross stratifications could be interpreted as: (i) storm-generated wave currents (suggesting a water depth lower than 200 m, Harms et al., 1975; Cheel and Leckie, 1993); (ii) an oscillatory component during traction plus fallout produced by sediment-laden hyperpycnal flows (e.g. Mutti et al., 2003; Tinterri, 2007) or (iii) combined flow related to reflection and bounding processes on topographic obstacles, such as anticline crests (e.g. Muzzi Magalhaes and Tinterri, 
Section 2

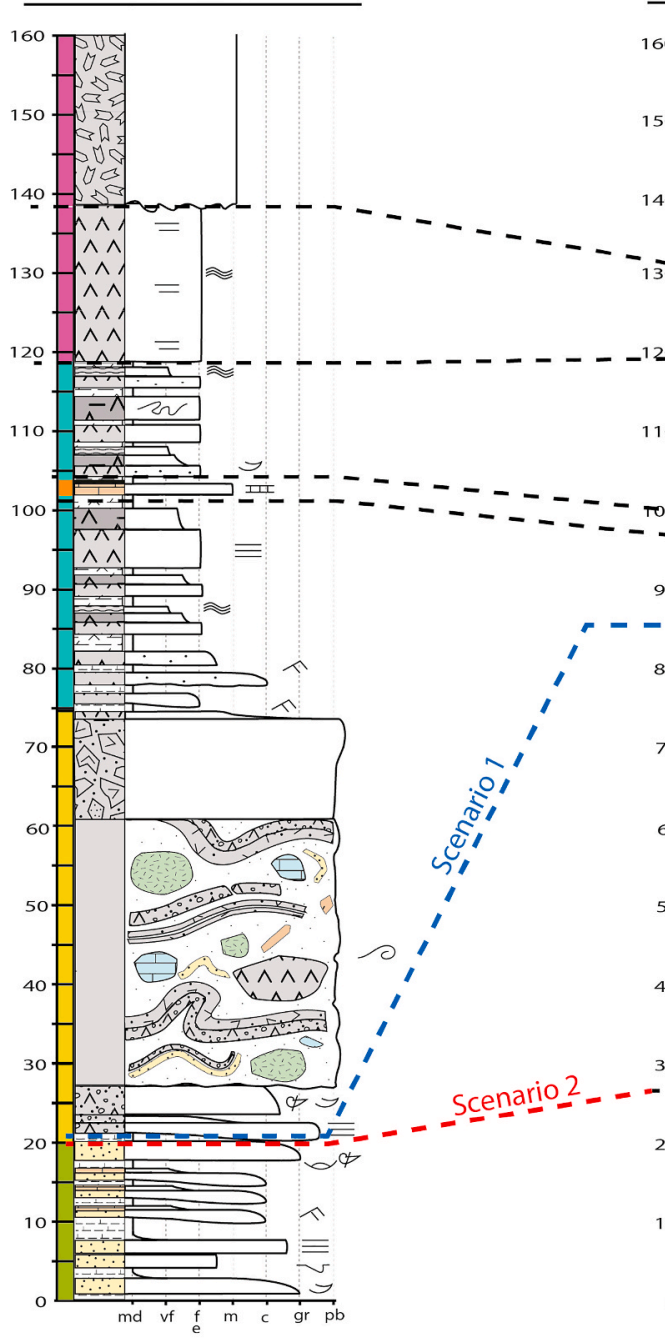

Facies associations

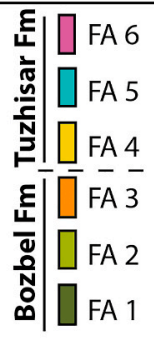

Section 1

Section 3

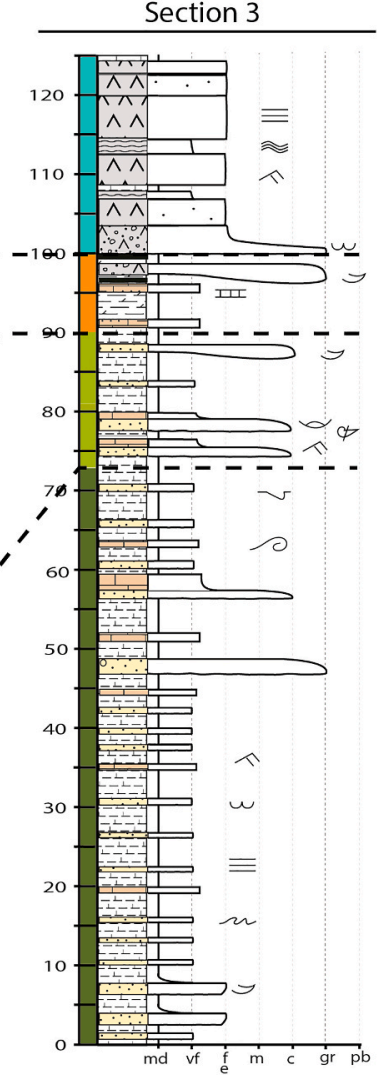

Main lithologies

gevy Macro crystalline gypsum - GF 3

EE:- Laminated gypsum - R7

$\dot{A} \hat{-}-\dot{A}$ Clay-rich gypsum - R6

$\therefore \wedge$ Massive to fine-grained gypsum - R3 to R5

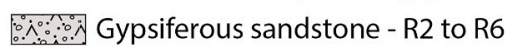

D. Gypsiferous debris flow - R1

Eypsum-rich dolomitic shales - GF 1

Dolomitic shales

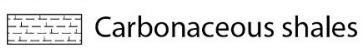

Organic-rich shales

II-I Silty mudstone

Mudstone

$\because \because$ Conglomerate

$\therefore$ Sandstone

Cretaceous to Eocene limestone

Ophiolite
Gypsum lithologies

$=$ Stacked tabular gypsum beds - GF2

2 Slurried gypsum bed - R1

Siliciclastic content

Sedimentary structures

$\exists$ Cross laminations
$\equiv$ Parallel laminations
$\approx$ Mega ripple
$\approx$ Current ripple
$\approx$ Hummocky cross-stratifications
$\approx$ Convolute laminations
$\approx$ Wavy laminations
$\curvearrowright$ Slump

v Scour and fill

$\checkmark$ Flute cast

$\sim$ Load cast

$\phi$ Bioclasts

$\oslash$ Plant fragment

$\checkmark$ Burrow

- Pyrite nodule

III Calcite beef veins

pb: pebbles, gr: granules, $c, m$, f and vf: coarse, medium, fine and very fine grained sandstone, e: evaporites, md: mud

Fig. 5. Simplified sedimentary logs of sections 1 to 3 in the Upper Eocene Bözbel Formation and in the Tuzhisar Formation and proposed correlations. 

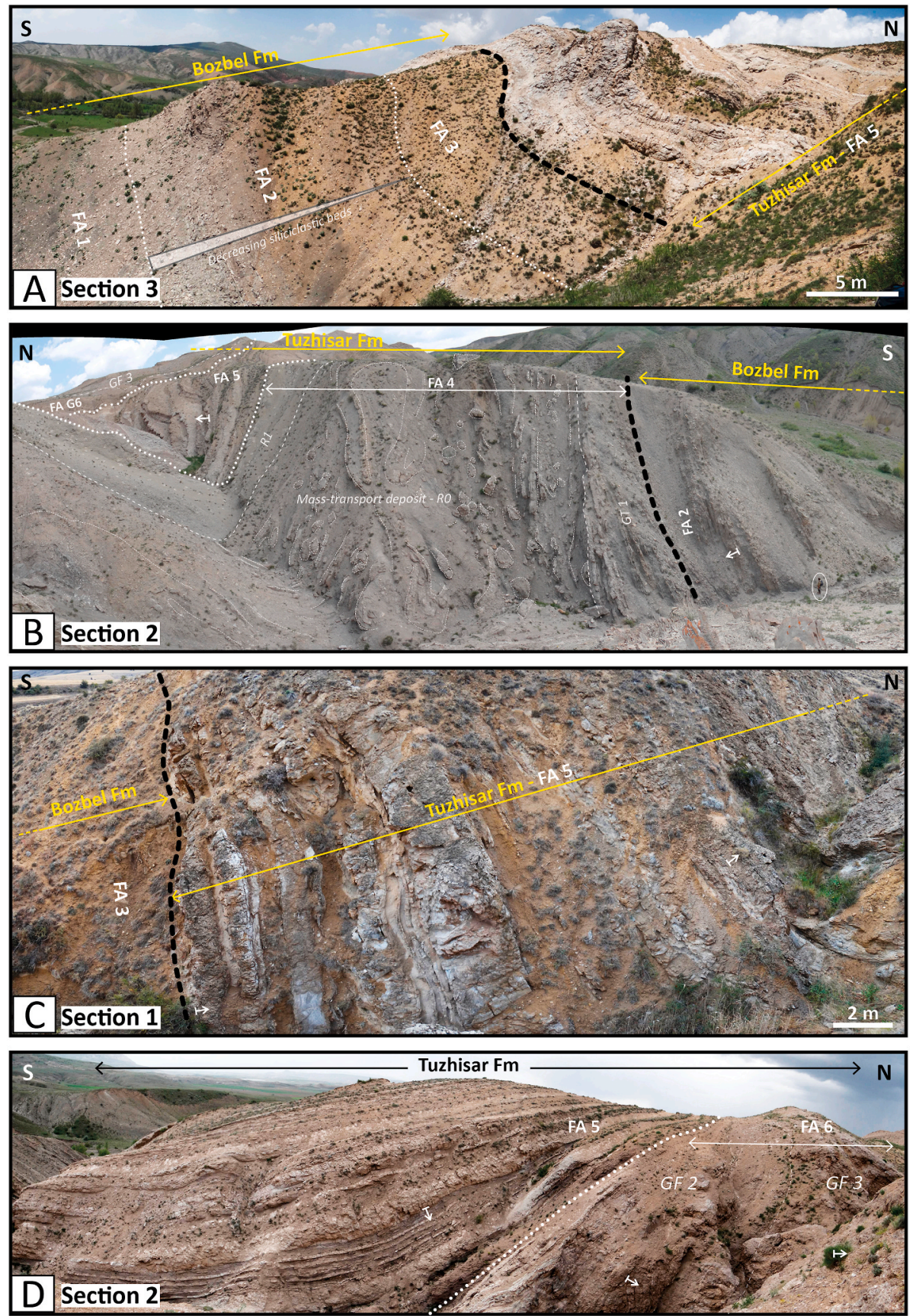

Fig. 6. Landscape view of the three studied sections. The dip symbol points to the top of the beds. See Fig. 4 for the location of each landscape views.

2010; Tinterri, 2011). The mudstones facies capping the sand bodies have accumulated through traction plus fallout processes from the diluted tail. Ponding and rebound processes of the turbidity currents may as well explain some of the calcareous mudstone divisions as resulting from the erosion, resuspension and sedimentation of the hemipelagic deposits that had originally developed on the bounding slopes which confined the turbiditic flows (Mutti et al., 2002). Finally, the thin silty to medium grained sandstones (ST1) and the calcareous mudstone (ST3) deposited by traction-plus-fallout processes in diluted turbulent flows, possibly further downcurrent of the coarser deposits.

\subsubsection{SF1, massive mudstones}

This facies forms 1 to $80 \mathrm{~cm}$-thick moderately competent to fissile blueish or beige mudstones (Fig. 9 A). They are structureless or locally show discrete parallel laminations. In thin sections, the mudstones display a clotted calcimicrite texture, with some dark flame to funnel structures, and enclose dispersed silt-size planktonic foraminifers globigerinae, bivalve debris detrital clay, quartz grains and framboidal pyrite (Fig. 9 B, C and D). Skeleton internal voids and vugs are filled by sparite (Fig. 9 B).

This facies is interpreted as a recording chemical precipitation in calcite-saturated water column (possibly due to evaporative condition, e.g. Manzi et al., 2011; Decima et al., 1988) and/or detrital particle settling of micritic mud previously deposited under shelf environment (e.g. Plint, 2014). Minor terrestrial inputs are evidenced by the dispersed silt-sized fraction and the absence of wave ripples suggests a water depth below the storm wave base. Planktonic foraminifer fossils could relate both from marine incursion or terrestrial reworking from intra-basinal exhumed platforms. Dark flame to funnel structures probably record burrowing activity but the absence of well-developed biota suggests 


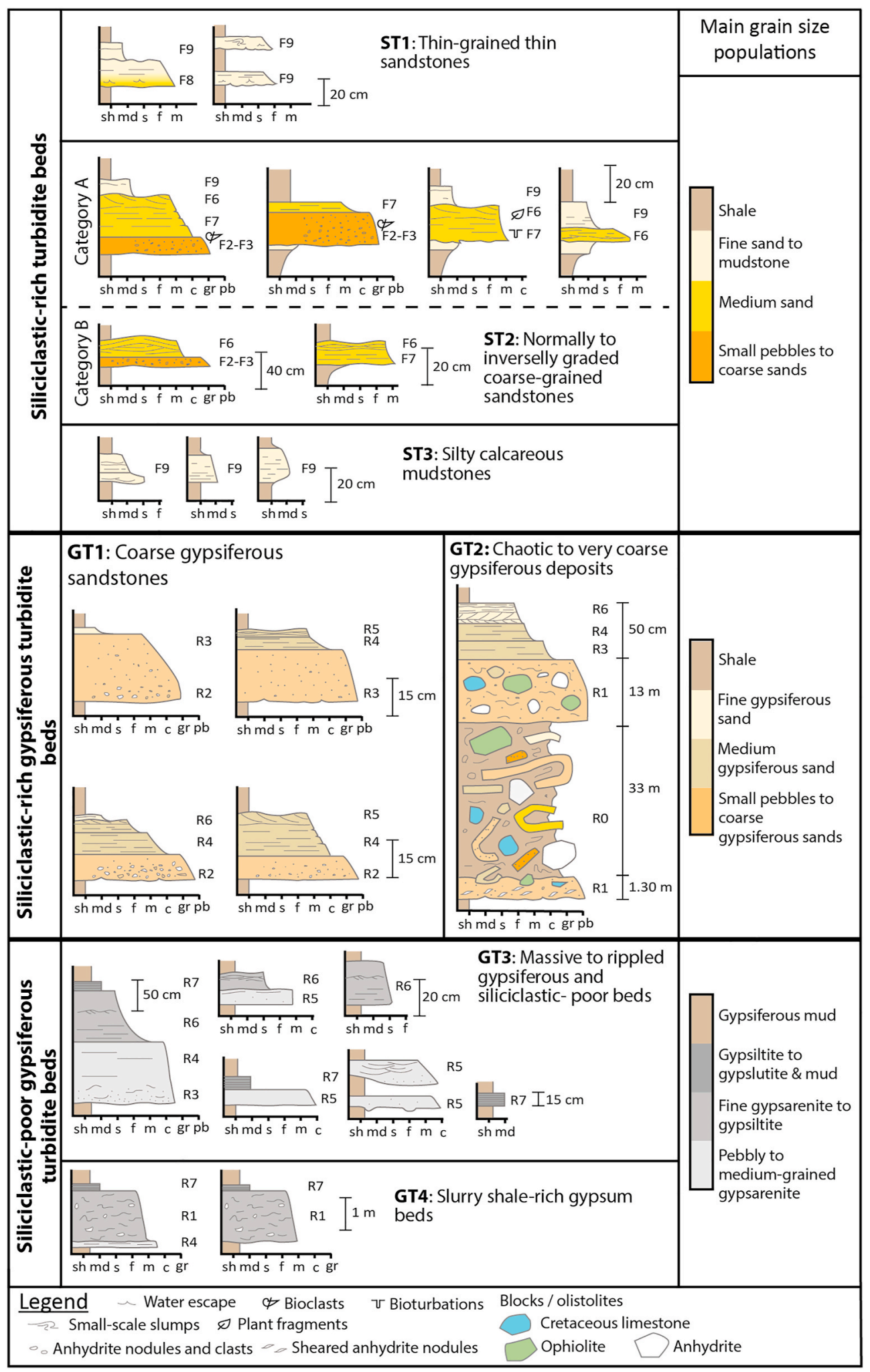

Fig. 7. Synthesis of the main bed types related to turbidity currents in the upper Bözbel Fm and in the Tuzhisar Fm. F2 to F9 refer to Mutti et al. (2003) facies nomenclature, with F6-F7 facies which tend to be finer-grained in the Bozbel Fm than in the original nomenclature. R0 to R7 refer to Manzi et al. (2005) facies nomenclature.

ecological stress (e.g. Elliott and Warren, 1989). Framboid pyrite may relate to bacterial-mediated iron precipitation in anoxic conditions during or after deposition (Williams-Stroud, 1994). Finally, the clotted micritic texture may results from (i) flocculation processes during settling (e.g. Plint, 2014), (ii) the occurrence of faecal pellets (e.g. Dela
Pierre et al., 2014) or (iii) bacterial activity (e.g. Guido et al., 2007).

\subsubsection{Facies associations}

The Bözbel Formation may be subdivided in three facies associations. 

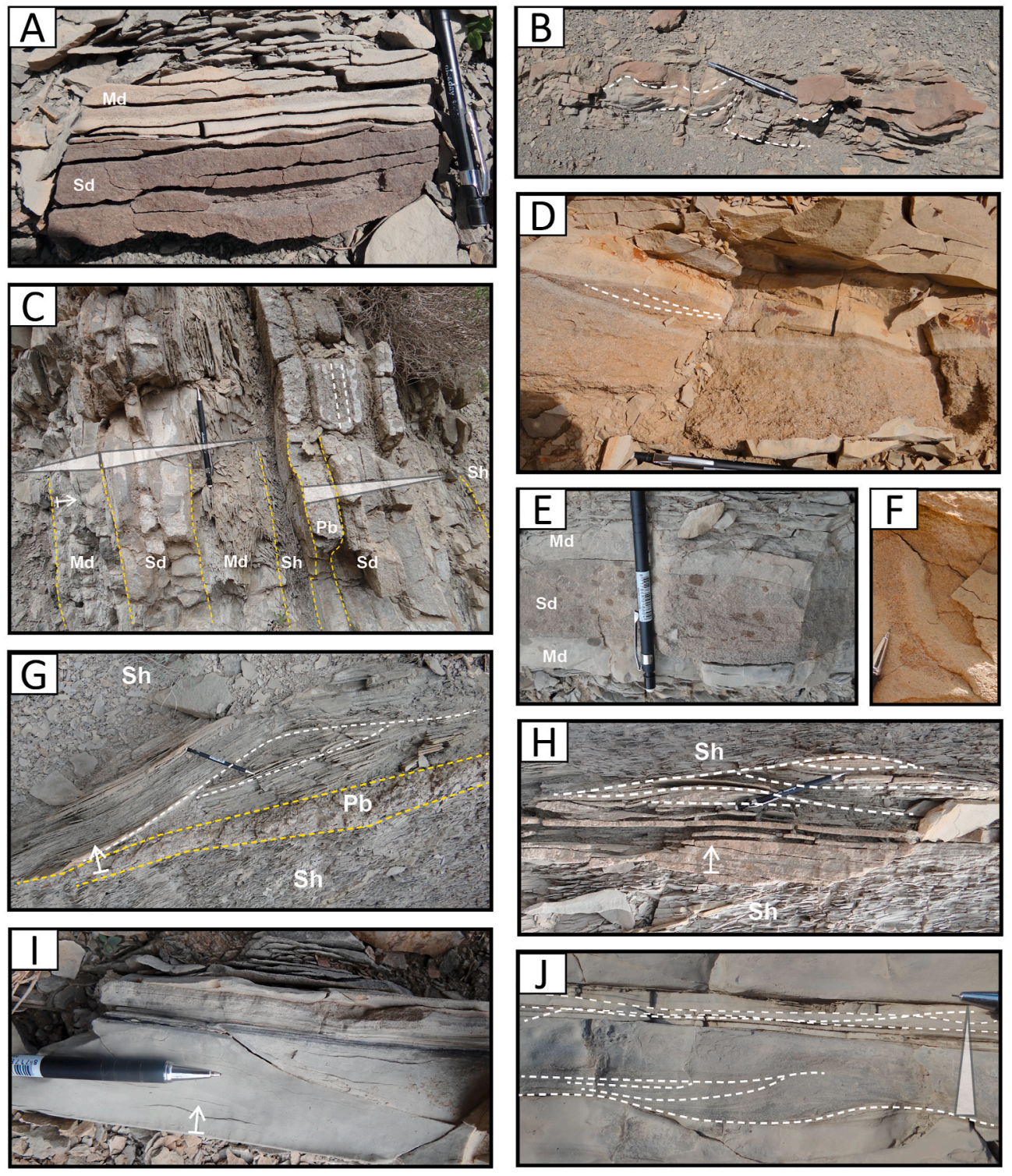

Fig. 8. A: Sandstone bed rippled on top and capped by mudstone deposits B: Sandstone bed displaying loading structures. C: Alternating normally to inversely graded mudstone (Md), shales (Sh) and normally graded pebbly $(\mathrm{Pb})$ to fine-grained (Sd) sandstone beds. D: Scoured and rippled sandstone bed capped by mudstone facies. E: Inversely graded mudstone capped by an erosive sandstone bed, itself capped by a normally graded mudstone bed. F: Horizontal coarse sandstone-filled burrow within a medium-coarse sandstone bed. G: Pebbly sandstone capped by a medium-grained sandstone displaying hummocky-cross stratifications. H: Small-scale hummocky-cross stratification in a sandstone bed. I: Parallellaminated mudstone. J: Normally graded, scoured and siliciclastic-rich mudstones with cross-ripples. Note the wavy bedding of the thin mudstone bed just below the pen point.

\section{d. FA1: Pro-delta deposits}

This facies association is mainly composed of grey shales and marls alternating every $4-50 \mathrm{~cm}$ with thin silty to medium-grained fining upward sandstone and scarce calcareous mudstone beds (ST 1 and 3) (Fig. 9 E).

This facies association is interpreted as characterizing distal finegrained and thin-bedded hyperpycnites in a prodelta environment (e. g. Mutti et al., 1999, 2003; Bhattacharya and MacEachern, 2009). Shales and marls were formed by slow suspension settling during fair-weather periods, whereas sandstone emplaced from periodic/seasonal river discharges in the basin (e.g. Mutti, 1977; Mutti et al., 2003; Bhattacharya and MacEachern, 2009).

\section{e. FA2: Delta front deposits}

This FA is composed of regular bed alternations of grey shales, marls, calcareous mudstones (ST 3) and coarse to fine grained sandstones of bed types $2 \mathrm{a}$ and b (Fig. 9 F). These deposits are locally affected by several meter-thick slump folds (Fig. 9 F). Flute casts in basal sandstones indicate an overall westward paleocurrent, in accordance with flow directions reported by other authors in the Bözbel Formation (Artan and
Sestini, 1971; Cater et al., 1991; Rouby, 2015). In sections 1 and 3, sandstone beds become increasingly scattered upward (Fig. 6 A). Moreover, scarce isolated sandstones beds in section 1 and 3 carry gypsum granules (Fig. $9 \mathrm{G}$ and $\mathrm{H}$ ).

The FA2 is interpreted as characterizing hyperpycnites deposited in a distal delta-front environment with clastic discharges sourced from the eastern part of the basin (e.g. Mutti et al., 1999, 2003; Mulder et al., 2003). The sandstone and mudstone hyperpycnites result from periodic/seasonal river discharges, whereas the shales mark suspension settling of fine-grained material during fair-weather periods (e.g. Mutti, 1977; Mutti et al., 2003; Bhattacharya and MacEachern, 2009). In section 2 and 3, the decreasing occurrence of siliciclastic deposits highlights a progressive starvation. The occurrence of gypsum granules in scarce sandstones of section 1 and 3 suggests the reworking of primary gypsiferous deposits possibly precipitated landward under arid conditions.

\section{f. FA3: Sediment-starved slope environment}

The FA3 is dominated by light grey to brown silty shales evolving toward blueish or beige fissile marls and moderately competent massive mudstones (SF 1; Fig. 9 I). These muddy facies are interlayered with 



Fig. 9. A: Silty mudstone bed. B: Micrite texture of the mudstone bed carrying quartz grains (most of the white dots), clay flakes (mica flake highlighted by the yellow arrow), and pyrite concretions (white arrow) (optical photomicrograph, XPL). C: A planktonic foraminifer test in the silty mudstone. The white arrow points to pyrite concretions (optical photomicrograph, PPL). D: Darkened/compacted micritic texture (yellow dots) in the silty mudstone, probably resulting from bioturbation (optical photomicrograph, PPL). E: Thin sandstone and marl alternations of facies association 1 of the Bözbel Fm. (the white circle highlights a pen for the scale). F: Regular alternations of grey shales, marls, mudstones and sandstones in FA2. White dots highlight a slumped interval. G: Microconglomerate carrying gypsum granules (whitish grains, yellow arrows). H: Thin section of the microconglomerate in picture $G$, with gypsum and serpentinite grains (white dots, G, and Spr respectively) in micritic matrix (Mcr). Yellow arrows point diagenetic recrystallized automorphous gypsum crystals. I: Tabular beds of silty mudstones interlayered with shale deposits in FA3. J: Thin alternations of silty mudstones (Md), sandstone (Sd) and shales (Sh) some of which are organic-rich (white arrows) and surrounded by bed-parallel fibrous calcite veins (Ca, yellow dots and arrows). black shales crossed by bed-parallel fibrous calcite veins that display a characteristic oil smell when broken (Fig. $9 \mathrm{~J}$ ).

This facies association is attributed to suspension settling of detrital particles (shales and marls) to organic matter (organic-rich shales) and possible carbonate precipitation (SF1) in a low energy subaqueous, sediment-starved, slope environment. Bed-parallel fibrous calcite veins in black shales are close to the calcite beef like evidenced in the Neuquen basin in Argentina and that are reported to maturation processes during burial of organic-rich shales (Cobbold et al., 2013; Larmier et al., 2021). The black shales probably accumulated in bottom anoxic water of a stagnant stratified water body (e.g. Raup and Hite, 1992; Rouchy et al., 1998; Dela Pierre et al., 2014; Karakitsios et al., 2016).
6. Sedimentological description and depositional environments of the Tuzhisar Formation (Bartonian): evaporitic facies

Because sulphate minerals can be intensely affected by diagenetic transformations (e.g. Testa and Lugli, 2000; Kasprzyk, 2003), it is of prime importance to establish in the Tuzhisar Formation whether the mineral textures of the gypsum beds are primary or secondary. In this perspective, it is necessary to characterize first the petrography of the gypsum deposits in the siliciclastic-rich deposits (FA4 and 5).

\subsection{Petrographic characterization of gypsum facies}

Three distinctive gypsiferous textures have been observed in the 
clastic-rich gypsiferous facies: (i) massive white gypsum, (ii) finegrained white gypsum and (iii) massive dark to yellowish gypsum. These three gypsum textures enclose granule to silt-sized siliciclastic grains, in variable proportion (from 0 to $80 \%$ of the gypsum beds). They are further described as follow:

Massive white gypsum: The massive white gypsum displays a competent white to light grey alabastrine texture (Fig. 10 A), sometimes highly distorted or affected by centimeter-to meter-wide, more or less coalesced, gypsum nodules (Fig. 10 B). It also frequently encloses gypsum porphyroblasts (Fig. $10 \mathrm{~A}$ ). In thin section, this texture shows closely interlocked xenotopic to amoeboid gypsum crystals enclosing anhydrite inclusions, single bladed gypsum crystals, micrite and/or micro-sparite grains (Fig. $10 \mathrm{C}$ ).

Fine-grained white gypsum: The fine-grained white gypsum displays a powdery saccharoidal texture locally enclosing gypsum porphyroblasts (Fig. $10 \mathrm{D}$ and E). In thin section, this texture shows a chaotic meshwork of idiotopic gypsum crystals mixed up with fine-grained microcrystalline gypsum and micrite grains (Fig. $10 \mathrm{~F}$ and G). Bladed crystals are partly sutured and can have discrete overgrowths. Locally, the crystalline meshwork is cemented by a poikilotopic cement. The gypsum porphyroblasts are especially rich in anhydrite inclusions (Fig. $10 \mathrm{G}$ ).

Massive dark to yellowish gypsum: The massive dark to yellowish gypsum displays a competent lithology which can be distorted by gypsum porphyroblasts or, more commonly, by white gypsum nodules (Fig. $10 \mathrm{H}$ ). It is as well frequently affected by satin-spar gypsum veins. In thin section, the lithology shows three subfacies: microcrystalline gypsum, amoeboid gypsum with anhydrite inclusions or sub-euhedral to euhedral gypsum crystals forming a mosaic fabrics (Fig. $10 \mathrm{I}$ and J). The whole subfacies trap a contorted micritic clayey matrix responsible of the dark color of this facies.

Interpretation of the petrographic textures: The massive alabastrine to nodular textures, the gypsum porphyroblasts, the amoeboid to mosaic
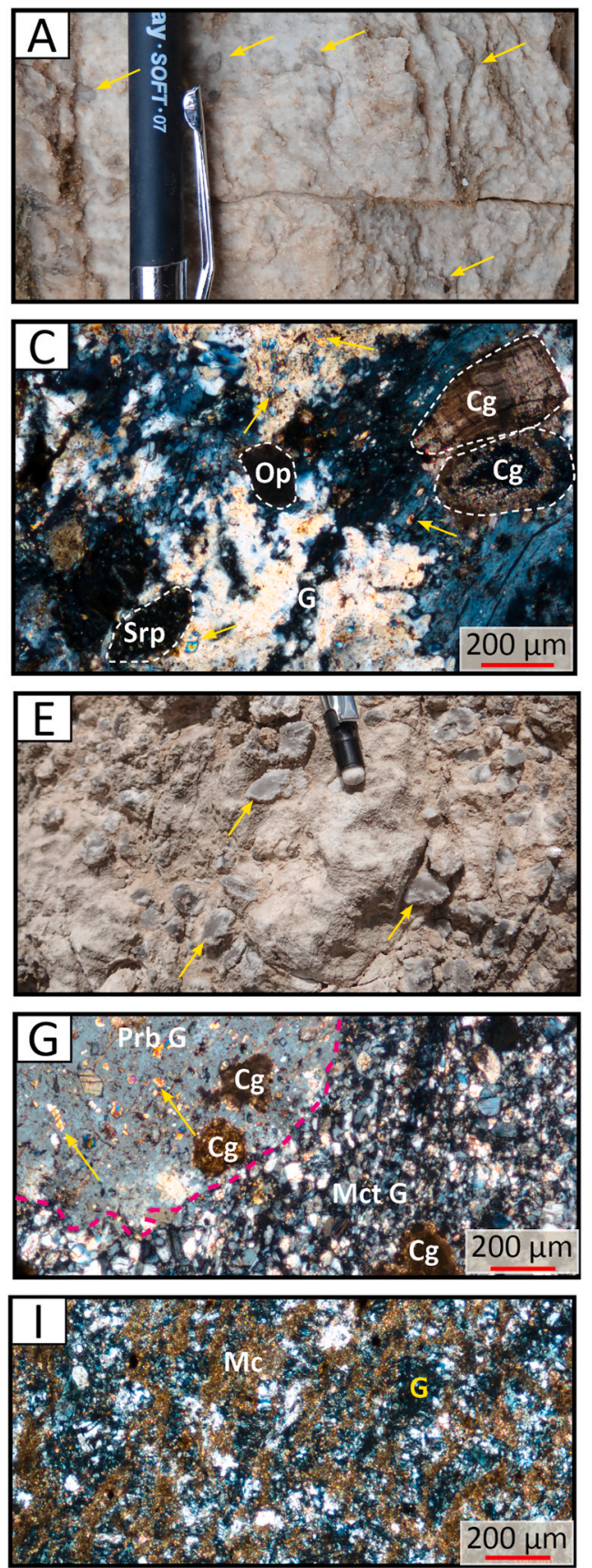
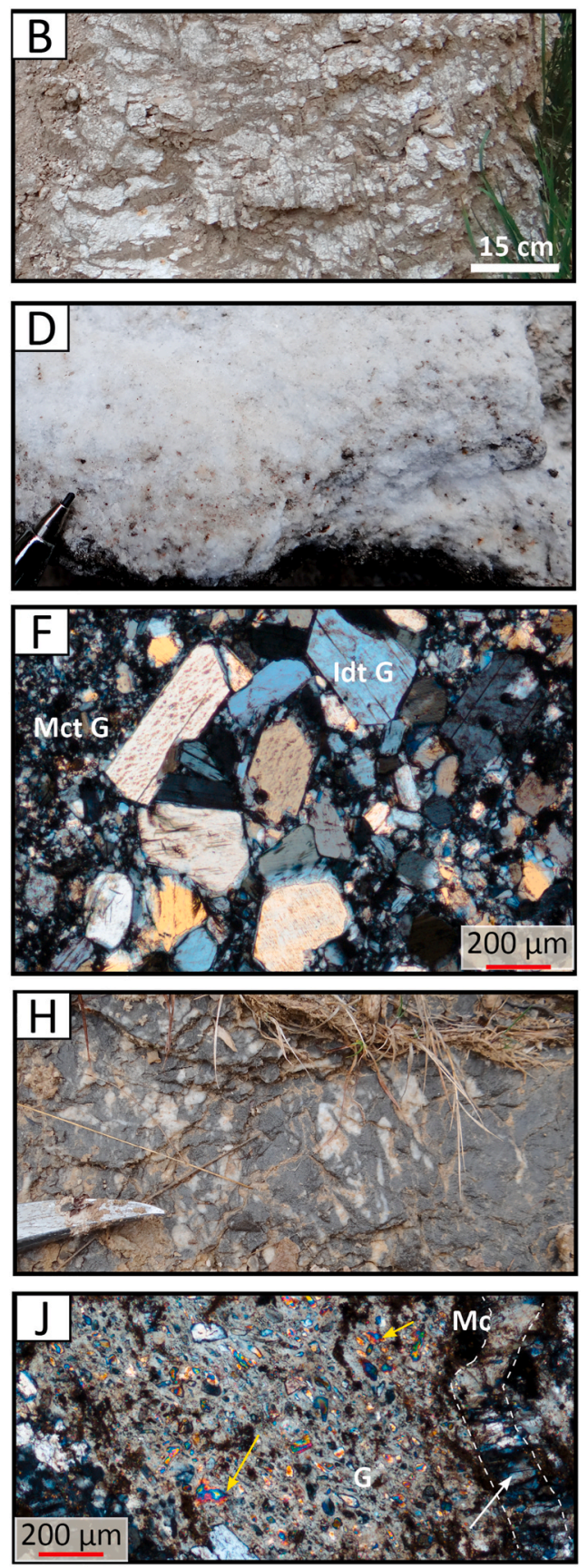

Fig. 10. A: Massive white gypsum enclosing gypsum porphyroblasts (yellow arrows). B: Massive white gypsum with a nodular texture. C: Xenotopic gypsum (G) enclosing anhydrite inclusions (yellows arrows). Note the siliciclastic and carbonate detrital grains (Cg: carbonate grain; Op: opaque mineral; Srp: serpentinite grain) enclosed in the gypsum (optical photomicrograph, XPL). D and E: Fine-grained gypsum rich in siliciclastic grains and enclosing gypsum porphyroblasts (yellow arrows). F: Microcrystalline gypsum (Mct G) enclosing micrite grains (Mc) (optical photomicrograph, XPL). G: Gypsum porphyroblast (top left corner, Prb G) within microcrystalline gypsum (Mct G). The porphyroblast is enclosing anhydrite inclusions (yellow arrows) and detrital micritic carbonate grains $(\mathrm{Cg})$ (optical photomicrograph, XPL). H: Massive dark-grey gypsum with white gypsum nodules. I: Microcrystalline gypsum $(G)$ enclosing micrite grains (Mc). J: Amoeboid gypsum (G) enclosing anhydrite inclusions (yellow arrows) and micrite (Mc). The white arrow and dots point to a vein filled with satin-spar gypsum. 
microcrystalline habits, the anhydrite inclusions in gypsum crystals and the fibrous veins of gypsum demonstrate that all the gypsum textures are of secondary origin, i.e. resulting from the hydration of precursor anhydrite (Holliday, 1970; Rouchy et al., 1986; Warren, 1990). Such anhydrite was of primary origin, or, more likely, resulted from the dehydration of primary gypsum deposits (Hussain and Warren, 1989; Kasprzyk and Orti, 1998; Kasprzyk, 2003). The conversion of primary gypsum to anhydrite most probably occurred by temperature increase during burial (Murray, 1964), since up to $4 \mathrm{~km}$ of sediments have covered the Eocene evaporites during the Oligo-Miocene (Kurtman, 1973; Poisson et al., 2011; Kergaravat et al., 2016; Legeay et al., 2020) and since bituminous-rich calcite veins identified in the pre-evaporitic black shales (FA3) suggest a burial temperature higher than $65{ }^{\circ} \mathrm{C}$ (Cobbold et al., 2013). The present-day secondary gypsum formed during the exhumation of the sedimentary pile, when anhydrite was pervasively rehydrated to gypsum in the shallow active phreatic zone (Kasprzyk, 2003; Gindre-Chanu et al., 2015).

\subsection{Facies analysis}

As previously illustrated, gypsum-anhydrite transformations have considerably altered the primary sedimentary textures of the gypsiferous deposits. However, according to the stratal pattern, the siliciclastic content in the gypsum, and the primary sedimentary structures and textures locally preserved, we identify 4 bed types related to gypsiferous turbidity currents (GT 1 to 4, Figs. 7) and 2 facies mixing chemical and reworked gypsum deposits, and one facies produced by diagenetic processes (GF 1 to 3). The gypsiferous turbidite bed types are described following the nine facies types (R0 to R7) of Manzi et al. (2005) describing the down-current evolution of a waning and depletive gypsumclastites-bearing flow.

\subsubsection{GT1 to GT4, gypsiferous turbidity current bed types}

\section{g. GT1, coarse gypsiferous sandstones}

This bed type is composed of conglomeratic to fine-grained siliciclastic deposits mixed with up to $\sim 70 \%$ of gypsum (Figs. 7 and 11 ). The latter appears as (i) pebbles or granular gypsum clasts of alabastrine texture (Fig. 11 A), and (ii) a poikilotopic cement between the siliciclastic grains and/or (iii) a fine-grained gypsum matrix (Fig. 11 C). Beds are $0.1-1 \mathrm{~m}$-thick, normally graded, channelized to tabular. Loadcasts structures have also been observed at the base of some coarse-grained beds (Fig. 11 D). Bed types of GT1 display up to three successive subdivisions, from bottom to top: (i) a coarse-grained poorly sorted and crudely stratified subdivision with erosive base and sometimes associate
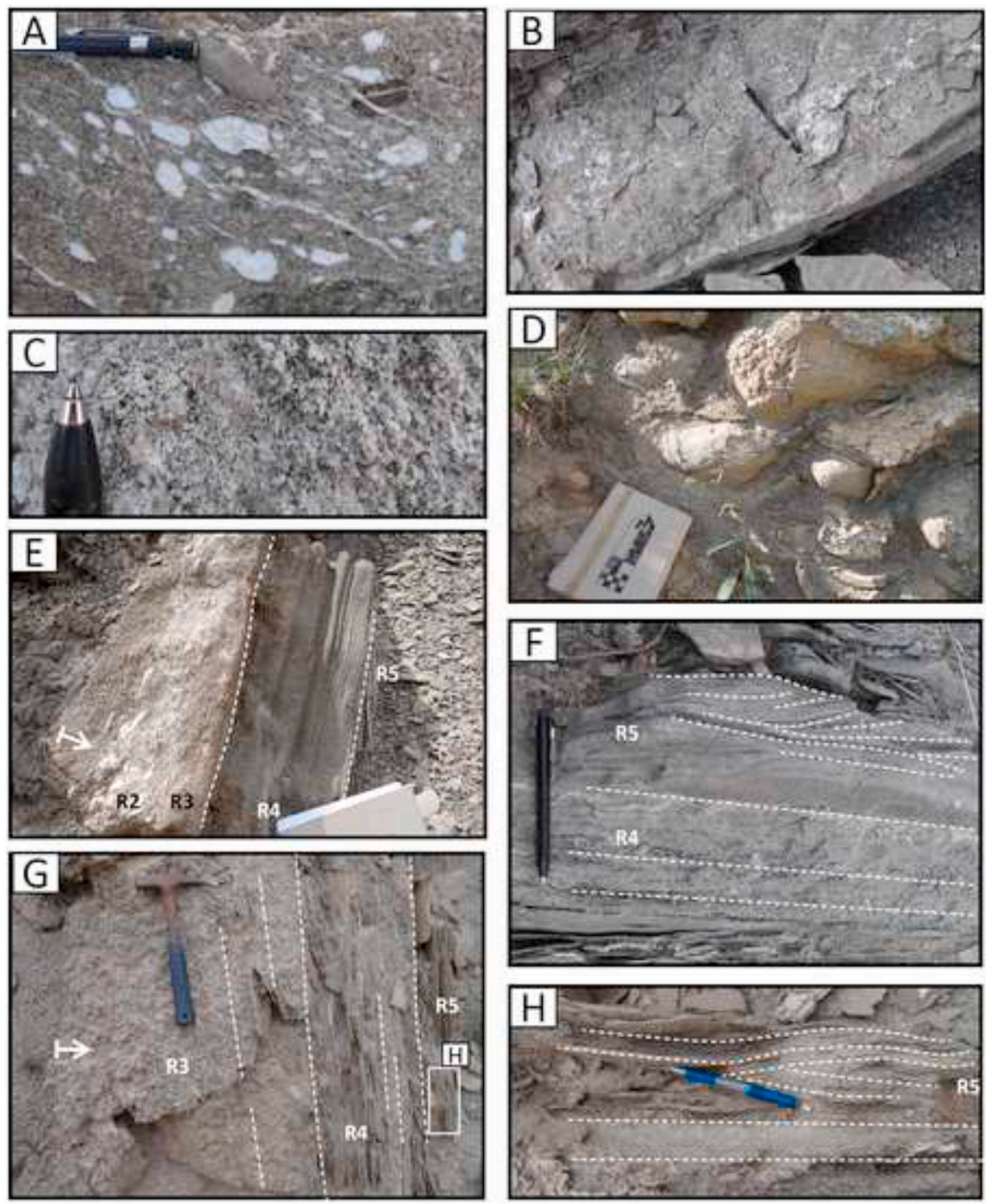

Fig. 11. A: Matrix-supported gypsum clast-rich conglomerate. B: Fining upward coarse-grained gypsiferous sandstone with a sharp erosive base. C: Fine-grained gypsarenite up with siliciclastic grains. D: Load-cast at the base of a coarse-grained gypsiferous sandstone bed. E: Normally graded gypsum-rich conglomerate to sandstone beds displaying three internal subdivisions (limited by the white dots). F: Plane-parallel laminated gypsiferous sandstone grading to megaripples. $\mathbf{G}$ - $\mathbf{H}$ : Massive gypsarenite bed grading upward to plane parallel laminations $(G)$ and hummocky cross stratifications within finegrained sandstone cemented by gypsum (H). R2 to R5 refer to Manzi et al. (2005) facies nomenclature. 
rip-up mud-clasts, (ii) a medium to fine-grained parallel-laminated sandstone, and (iii) a well sorted, fine-grained to silt-rich subdivision with current ripples to mega ripples or small-scale hummocky crossstratification (Figs. 7 and 11 E, F, G, H). The pebbles from the basal conglomeratic beds are composed among others of yellowish mudstone, Middle Lutetian Nummulites, Paleocene to Cretaceous carbonate rocks and ophiolitic rocks.

This bed type is interpreted as turbidite gypsum-rich deposits (e.g. Manzi et al., 2005). The internal subdivisions in beds evidence the progressive deceleration of a dense to turbulent turbiditic flow (Mutti et al., 1999, 2009; Lowe, 1982). The coarse-grained deposits refer to pebbly to coarse gypsarenite (R2 to R3 facies), whereas the capping medium to fine-grained beds subdivisions refer to former gypsarenites to gypsiltites (R4 to R6). The main composition of the pebbles of the basal conglomerates indicates the erosion or reworking of previous deposits possibly incorporated in the thrust sequence of the source area.

\section{h. GT2, chaotic to very-coarse gypsiferous deposits}

This composite bed type form a $48 \mathrm{~m}$-thick chaotic interval including (i) decimeter to tens of meter-wide blocks of alabastrine gypsum (Figs. 6 B, Fig. 12 A), Cretaceous to Eocene limestone (Fig. 12 B) or ophiolite pieces and (ii) folded, faulted and brecciated beds of the FA2 and of the GT1 bed types. The base of the interval is marked by a matrix supported gypsiferous unit in which bed parallel sigmoidal gypsum clasts are aligned (Fig. $12 \mathrm{C}$ ). The top of the interval is capped by a $15 \mathrm{~m}$-thick chaotic gypsiferous masse, including clasts ranging from sand-sized grains to meter-thick boulders, and supported by a fine-grained gypsum matrix (Figs. 6 B, Fig. 12 A, D). Clasts display the same composition than the underlying mega blocks (Fig. $12 \mathrm{D}, \mathrm{E}$ ). The top of the sequence is ending with a massive gypsum and siliciclastic-rich arenite division, with crude plane parallel lamination, and grading upward to a finegrained division displaying bi-directional current ripples and capped by wavy gypsiferous silts (Fig. 12 F).
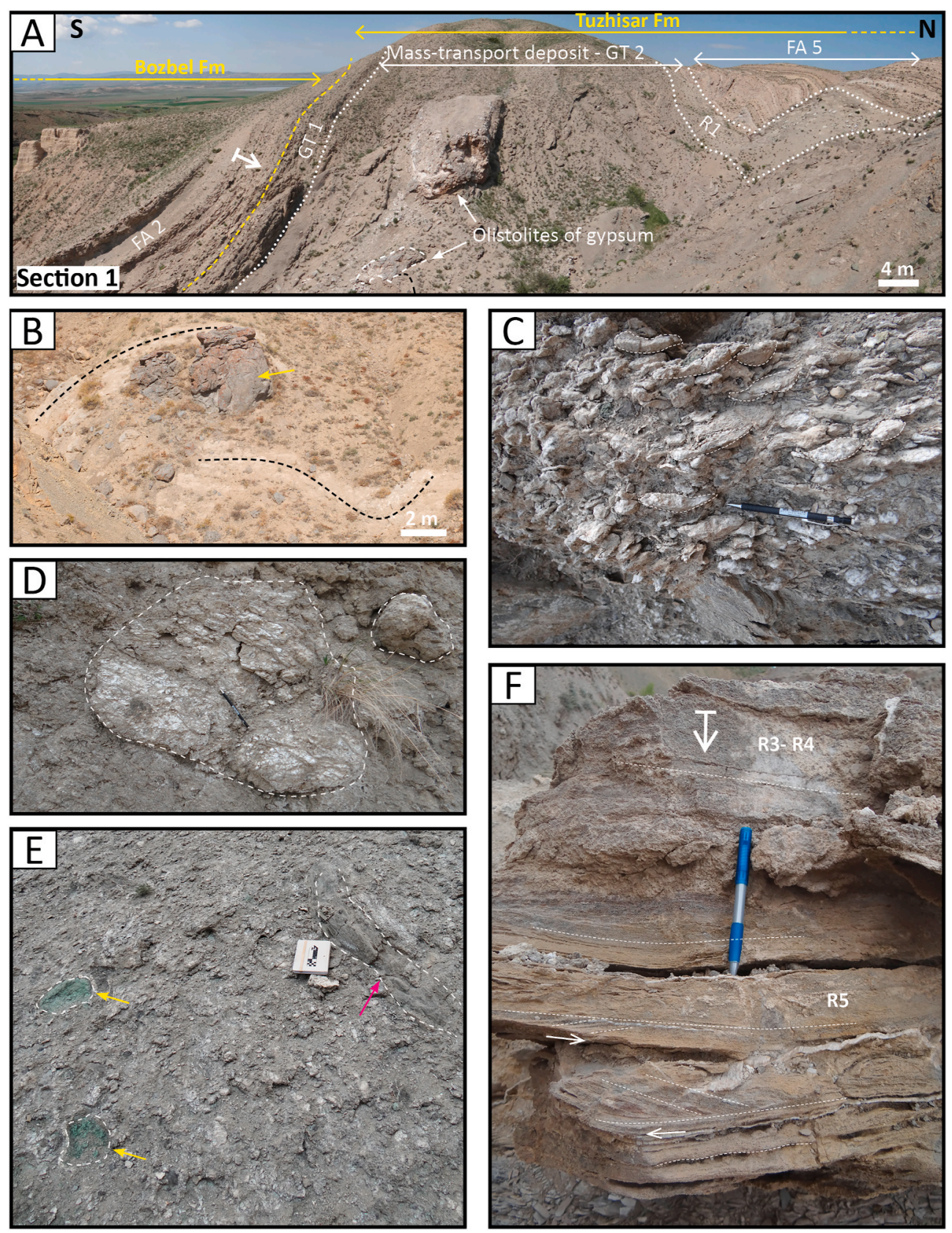
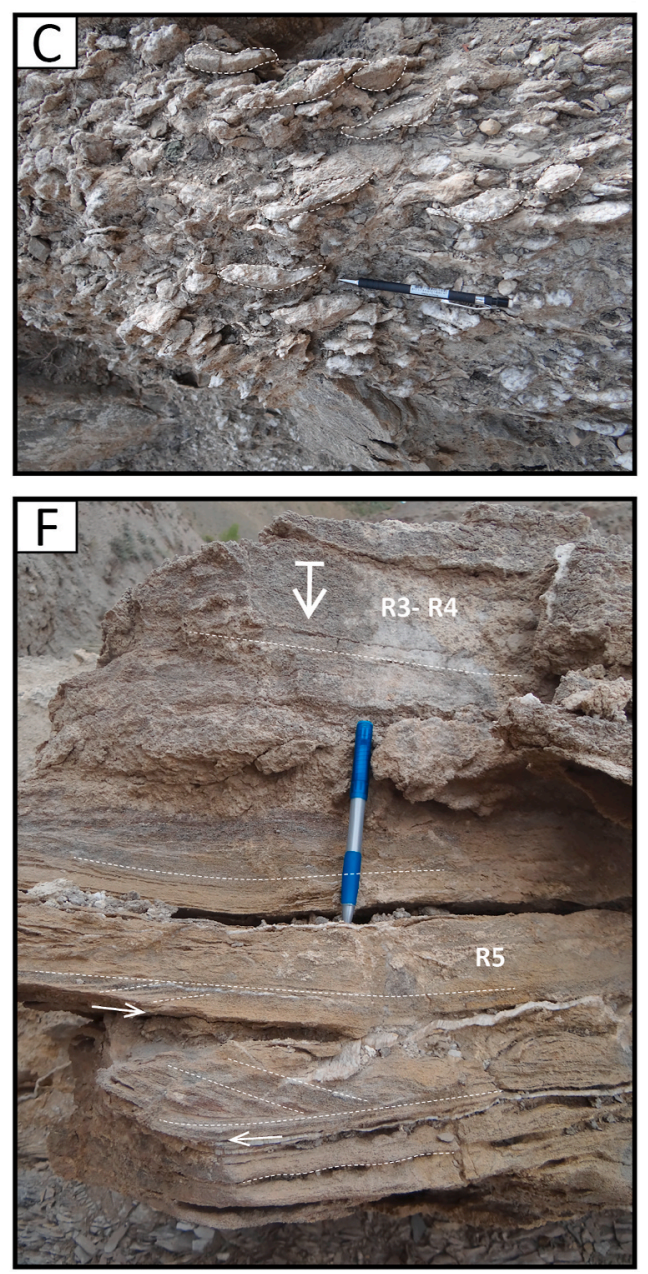

Fig. 12. A: Panoramic view of gypsum olistolites carried in a mass-transport deposit interval. B: Cretaceous limestone blocks (yellow arrow) embedded within folded gypsum beds (black dots). C: Base of the mega-slumped interval marked by a gypsiferous breccia where the gypsum clasts are bed-parallel and display a sigmoidal shape. D: Alabastrine gypsum boulder carried in a gypsum debris-flow. E: Gypsum-rich sandstone bed fragment (pink arrow) and ophiolitic blocks (yellow arrows) in the gypsum debris flow. F: Top of the gypsum debris flow capped by a normally graded siliciclastic-rich gypsum displaying parallellamination, bidirectional current-ripples (white arrows) and a wavy bedding. Here the series is upside-down. R3 to R5 refer to Manzi et al. (2005) facies nomenclature. 
The GT 2 is interpreted as a mass transport deposit related to a massive gravitational subaqueous collapse (e.g. Schlager and Bolz, 1977; Manzi et al., 2005; Gee et al., 2007; Ogata et al., 2012). The nature of the folded beds and olistoliths blocks shows that the landslide involved gypsum turbidites, ophiolitic basement-rocks, Cretaceous to Eocene platform limestone, and thick gypsum accumulations. The capping bouldery gypsiferous mass refer to a gypsum debris flow deposit related to a dense to cohesive gravity flow (R1, e.g. Schlager and Bolz, 1977; Manzi et al., 2005). The upward grading to rippled coarse to fine-grained gypsarenite (R3 to R6) records the turbulent suspension fallout that developed above the cohesive flow at the end of the catastrophic event (Postma et al., 1988; Mohrig and Marr, 2003; Mutti et al.,
2009; Arnott, 2010). The bi-directional current-ripples could indicate reflected-currents triggered by the basin floor confined geometry (e.g. Pickering and Hiscott, 1985; Haughton, 1994; Kneller and Branney, 1995; Remacha et al., 2005; Tinterri and Muzzi Magalhaes, 2011). Finally, at the base of this slumped section, the sigmoidal gypsum clasts probably indicate shearing along the basal plane of the slided section (Stow et al., 1996; Arnott, 2010).

\section{i. GT3, massive to rippled gypsiferous and siliciclastic-poor beds}

These beds are few centimeters-to 3 m-thick, tabular and include 3 subfacies (Figs. 7 and 13 A to D).
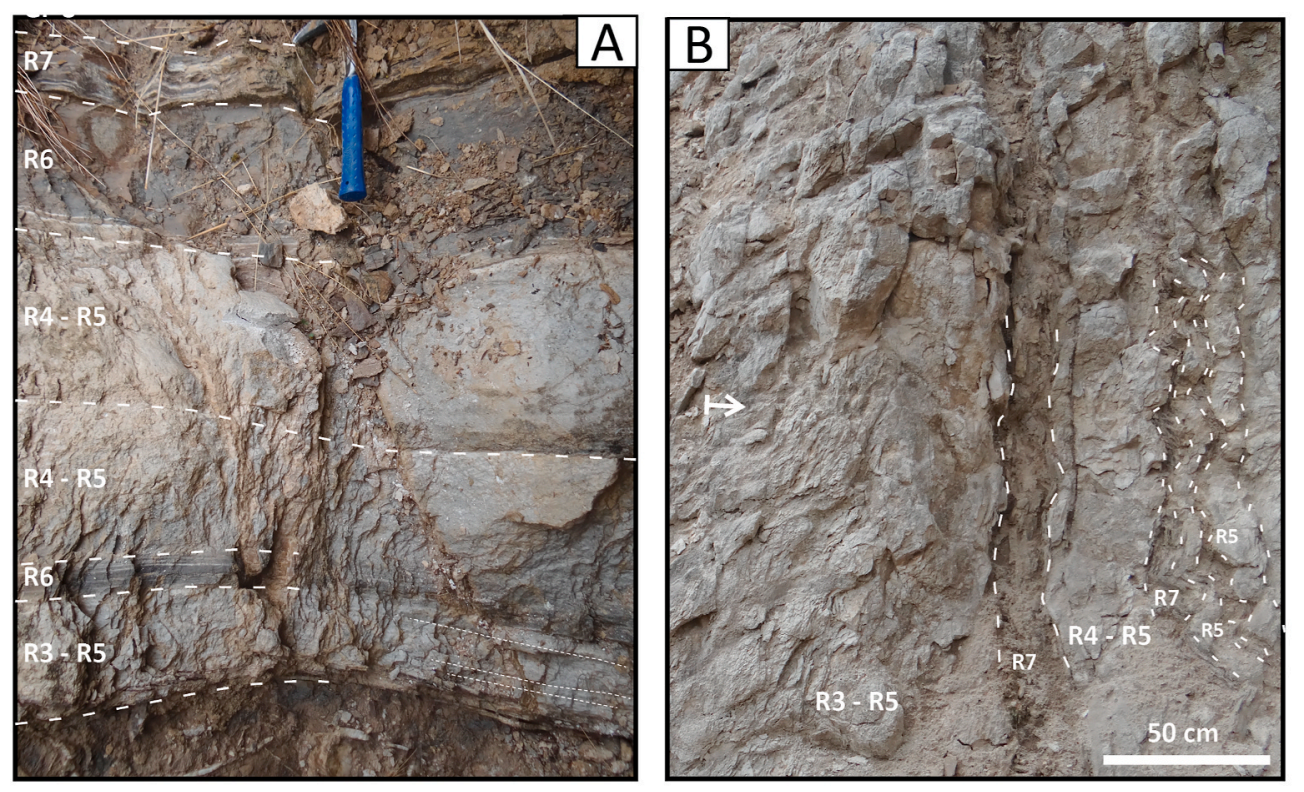

Fig. 13. A, B, C and D: Massive to finegrained whitish gypsum beds (R3-R5) grading to, or capped by clay-rich dark-grey gypsum layers (R6, picture $A$ and $\mathrm{C}$ ) or thinly laminated gypsum beds (R7, picture B and $\mathrm{D})$. The latter may be capped by shaly deposits (GF 1, picture A and C). Note the plane parallel laminations in picture A and C. E Massive alabastrine gypsum bed with normally-graded siliciclastic grains. F: Channelized fine-grained white gypsum with festoon-shaped trough cross-ripples. G: Alabastrine gypsum displaying current ripple marks. H: Single stored alabastrine gypsum bed displaying scouring structures. R3 to R5 refer to Manzi et al. (2005) facies nomenclature.
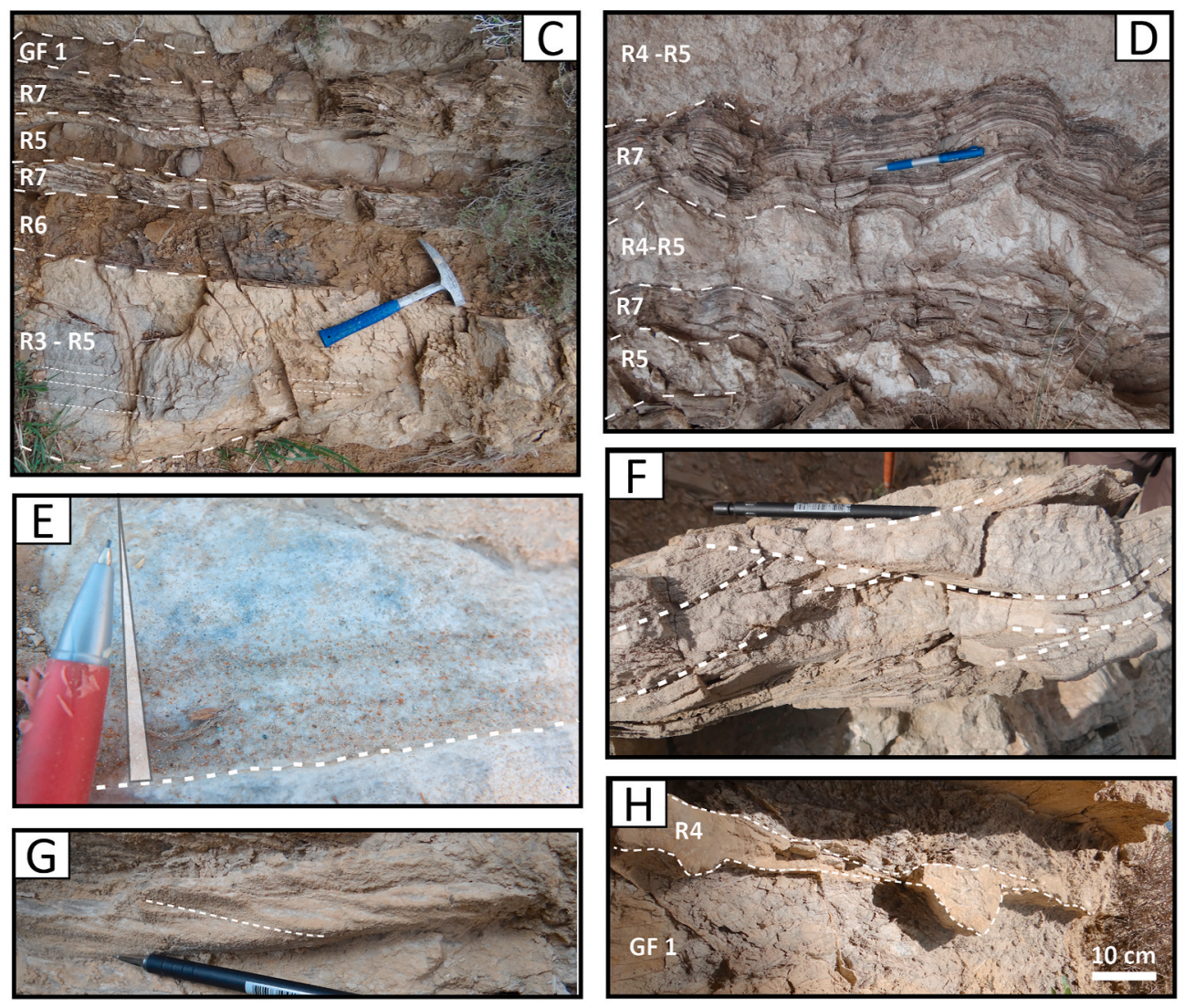
The basal subfacies is up to $2.5 \mathrm{~m}$-thick and displays a white to lightgrey gypsum having a fine-grained saccharoidal to massive alabastrine texture. It frequently encloses coarse to fine sand grains displaying an upward fining trend, at the base of the thickest beds especially (Fig. 13, E). Locally, the primary sedimentary fabric is preserved and includes plane parallel laminations, tabular and current ripples (Fig. $13 \mathrm{C}, \mathrm{E}, \mathrm{F}$, $\mathrm{G})$. When single, this subfacies may be channelized and display trough cross-laminations and scour-and-fill structures (Fig. 13 F, H).

The second subfacies is $10 \mathrm{~cm}$-to $2 \mathrm{~m}$-thick and displays a dark-grey to yellowish massive gypsum deposit with dispersed detrital grains (Fig. 13 A, B, Fig. 14 A). Sedimentary structures include parallel laminations, cross-ripples and small-scale hummocky cross laminae (Fig. 14 B, C). On thin-section, the gypsum is characterized by a micriticclayey mixed matrix of secondary gypsum. The muddiest facies drapes or encloses polygonal to angular secondary amoeboid gypsum crystals (Fig. 14 E, D). Such sand-sized crystal-like shapes can show a normal grading within the mud laminae (Fig. 14 D).

The third subfacies is $2-20 \mathrm{~cm}$-thick and characterized by millimeter-thick planar to highly undulating laminae of alternating dark-grey gypsum with microcrystalline white gypsum or grey carbonates (Fig. 14E and F). In thin section, the dark laminae show a secondary microcrystalline to mosaic gypsum enclosing disseminated micrite and/
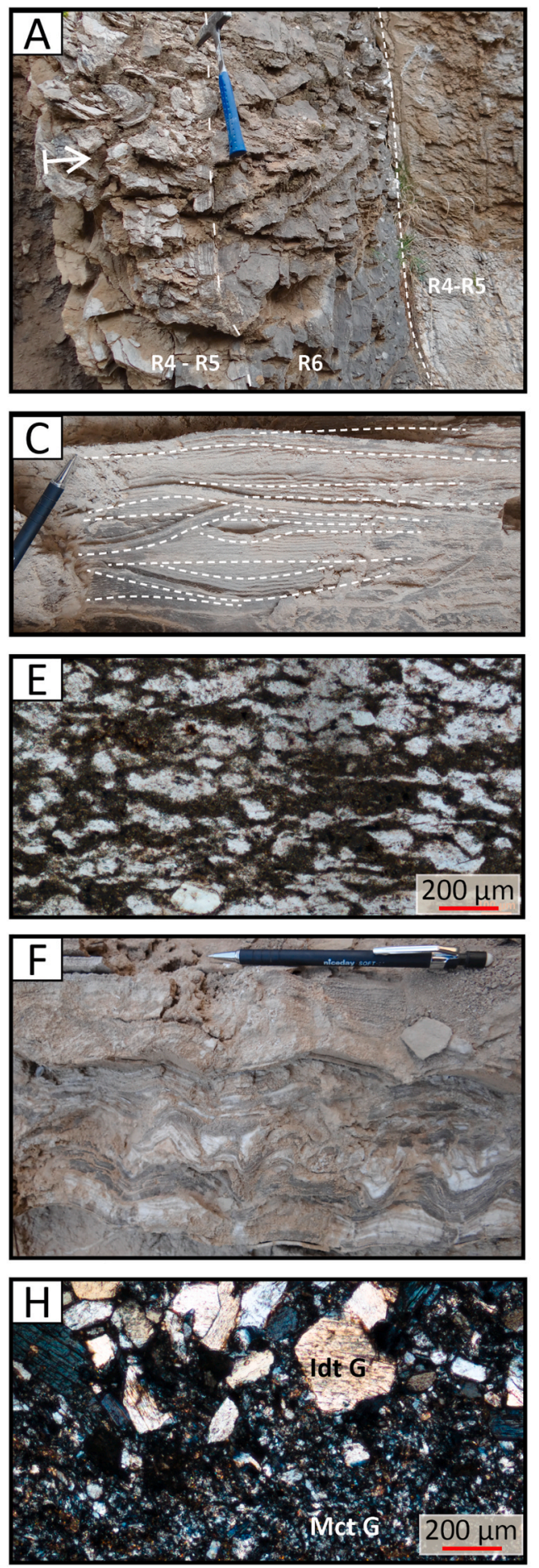
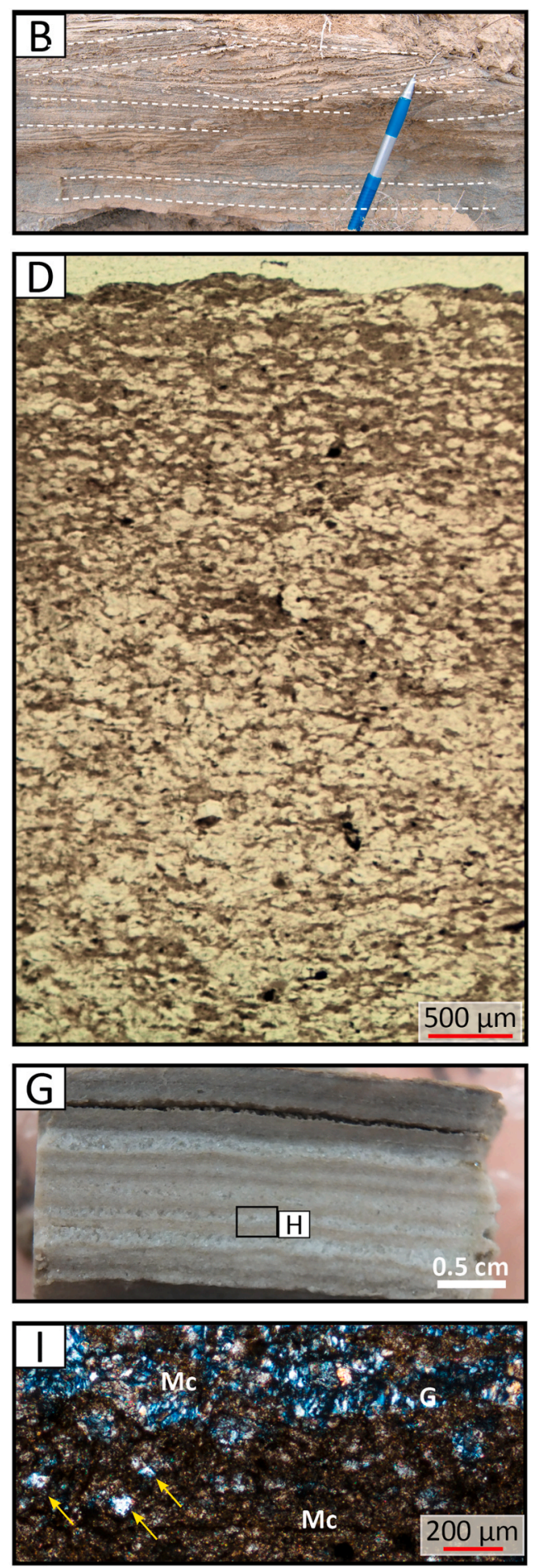

Fig. 14. A: Beds of massive white gypsum (R4-R5) grading to a massive dark-grey gypsum (R6). B and C: Massive dark-grey gypsarenite to gypsiltite displaying parallel laminations (B), cross-ripples (B) and hummocky cross-stratifications (C). D and E: micritic clayey matrix draping polygonal to angular shapes in the secondary gypsum (optical photomicrograph, PPL). In picture $\mathrm{D}$, note the sandstone-like texture outlined by the micritic clayey matrix, with an apparent normal grading of the gypsum grains. F and G: Laminated gypsum displaying undulating to planar alternation of white and dark gypsum laminae. H: Microcrystalline to amoeboid gypsum plus micrite (Mct G, dark laminae on picture F) followed by idiotopic crystalline gypsum (Idt $\mathrm{G}$, white laminae on picture D) (optical photomicrograph, XPL). I: Carbonate laminae made up of clays and micrite (Mc) enclosing sparse gypsum crystals (arrows) and surrounded by laminae made up of microcrystalline to idiotopic gypsum (G) mixed up with micrite and microsparite (optical photomicrograph, XPL). 
or microsparite. The white ones are composed of idiotopic gypsum crystals (Fig. $14 \mathrm{G}$ ). The carbonate laminae show muddy and peloidal micrite locally enclosing gypsum crystals (Fig. $14 \mathrm{H}$ ).

The siliciclastic content and the fining upward trend, associate to current ripples and the scouring structures, suggest the detrital origin of such composite gypsum beds (Manzi et al., 2005, 2016). In the second division, the sand-sized crystal-like shapes observed in the mud-laminae especially evidence former detrital gypsum crystals, since anhydrite clasts would display more rounded shapes (e.g. Rouchy and Sommers, 1995; Manzi et al., 2005). Accordingly, we interpret these bed types as gypsiferous turbiditic deposits (e.g. Manzi et al., 2005; Roveri et al., 2006). The basal subfacies refer to coarse to fine-grained gypsarenite (R3 to R5) emplaced by high to low density turbidity currents. The second subfacies refers to fine gypsarenite to gypsiltite (R6) related to low density turbidity currents (e.g. Rouchy and Sommers, 1995; Manzi et al., 2005). The third subfacies refers to fine gypsiltite and limestones resulting from very low density turbidity currents marked by suspension fallout processes (R7, e.g. Rouchy and Sommers, 1995; Manzi et al., 2005; Carrillo et al., 2014). In this last subdivision, the undulate shapes of the laminae result from the diagenetic transformations and/or soft sediment deformation (e.g. Peryt and Jasionowski, 1994; Lugli et al., 2015) whereas flocculation processes probably triggered the peloidal texture of the carbonate laminae.

The stacking of the three subfacies records thus a normal grading which evidences the progressive deceleration of a dense to turbulent turbiditic flow with the upper most facies deposited from the very low density dilute tail (Lowe, 1982; Mutti et al., 1999, 2009; Manzi et al., 2005). Sediment by-pass above the turbidite current may explain why R6 or R7 are locally absent above R5. Similarly, single R6 or R7 beds record the bypassed finer sediments carried by the turbulent flows farther downcurrent (e.g. Manzi et al., 2005).

\section{j. GT4, slurry shale-rich gypsum beds}

These beds are 0,7 to $2.80 \mathrm{~m}$-thick and display up to three subfacies. The basal one, when existing, is relatively thin (a few centimeters) and made of white albastrine gypsum with crude plane parallel lamination (R4). It passes upward to the second meter-thick subfacies displaying a slurred dark-grey gypsum with a flowing-like fabric, carrying many nonoriented clay-rich patches and white anhydrite nodules to stringers (Fig. 15A and B, C, D). Some anhydrite stringers display an angular shape that mimics former selenitic gypsum crystals (Fig. $15 \mathrm{C}$ ). The upper subfacies is few centimeters-thick and show a laminated dark-grey gypsum (as R7 facies in GT3, Fig. 15 A).

These beds characterize former shale-rich gypsrudite deposits (R1) emplaced in a cohesive debris flow having involved gypsiferous and mud-rich deposits (e.g. Rouchy and Sommers, 1995; Manzi et al., 2005; Roveri et al., 2006). The gypsum nodules and stringers are interpreted as
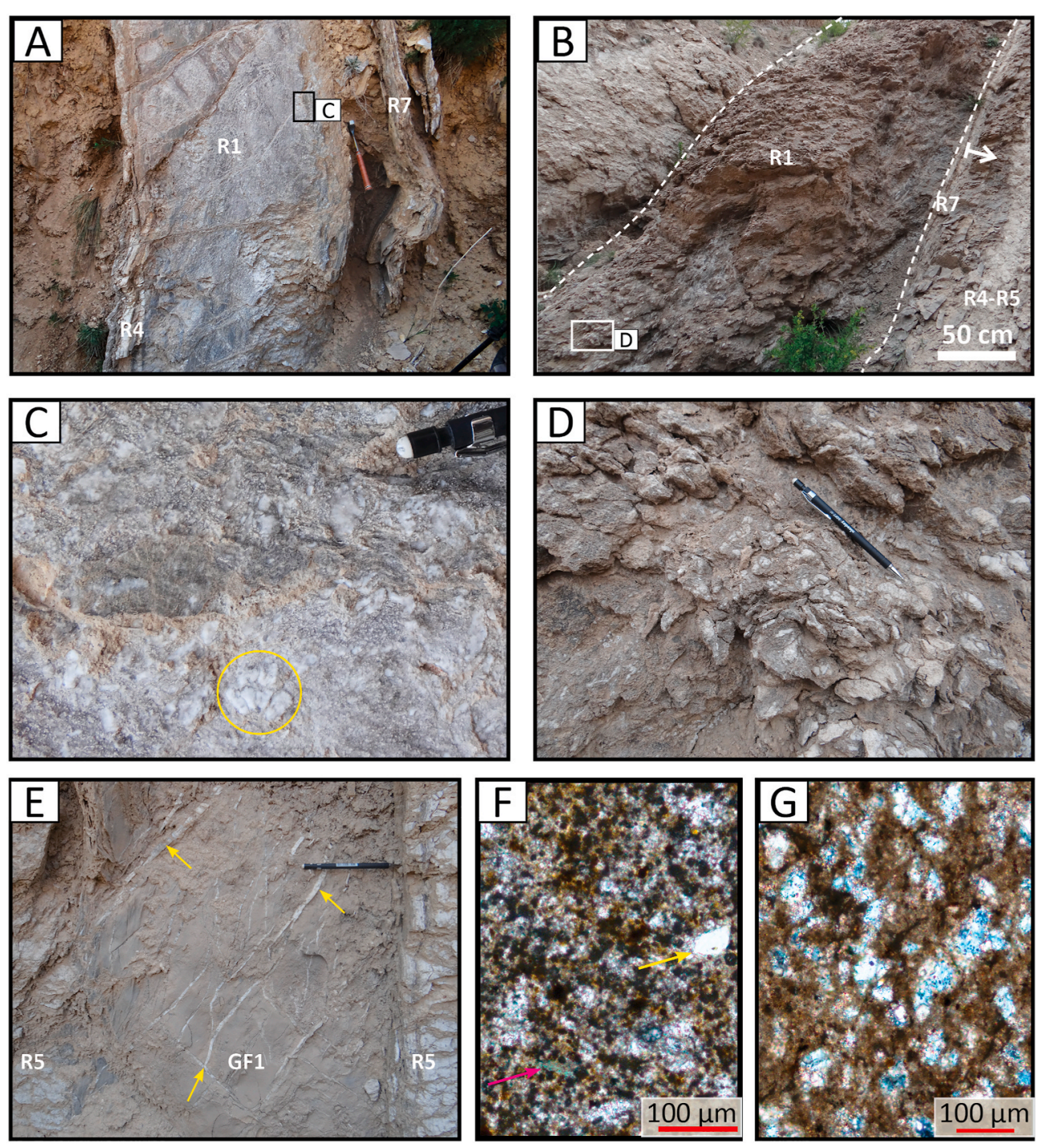

Fig. 15. A and B: Massive dark-grey gypsum beds displaying a massive/contorted texture. C and D: Zoom on gypsum nodules and stringers in the slurry shale-rich gypsum. On picture $\mathrm{C}$, the yellow circle highlights gypsum nodules that could correspond to former selenitic gypsum crystals. R3 to R5 refer to Manzi et al. (2005) facies nomenclature. E: Massive mud layer affected by satin-spar gypsum fractures (yellow arrows). F: Micrite and dolomicrite mixed up with flocculated clay aggregates (black dots) and enclosing quartz grains (yellow arrow) and a chlorite flake (pink arrow) (optical photomicrograph, PPL). G: Micritic clayey to dolomicritic matrix enclosing polygonal gypsum grains (optical photomicrograph, XPL). 
recording former detrital clasts, some of which were former gypsum crystals as supported by their selenitic shapes (e.g. Rouchy and Sommers, 1995; Lugli et al., 2013). Capping R7 facies records the by-pass of a more diluted and decelerating flow.

\subsubsection{Chemical and reworked gypsiferous deposits}

\section{k. GF1, Gypsum-rich dolomitic shales}

This facies is millimeters-to $50 \mathrm{~cm}$-thick and composed of grey to brown fissile shale to pelite and massive shaly calcareous mudstone, commonly affected by several joints filled with fibrous satin-spar gypsum (Fig. 15 E). In thin section, this facies shows a micrite to dolomicrite matrix mixed with dark clay aggregates and scarce silt-size grains of quartz, micas and chlorite flakes (Fig. 15 F, G). The gypsum may form a poikilotopic cement occluding coalesced polygonal to lenticular pores (Fig. $15 \mathrm{G}$ ).

These muddy beds are interpreted as fine chemical, detrital and possible diagenetic deposits settled from suspension and flocculation processes in subaqueous setting. They could have been emplaced by suspension settling of a lasting dilute cloud produced after a turbiditic event responsible for the composite bed types GT 1 to 4 . The detrital
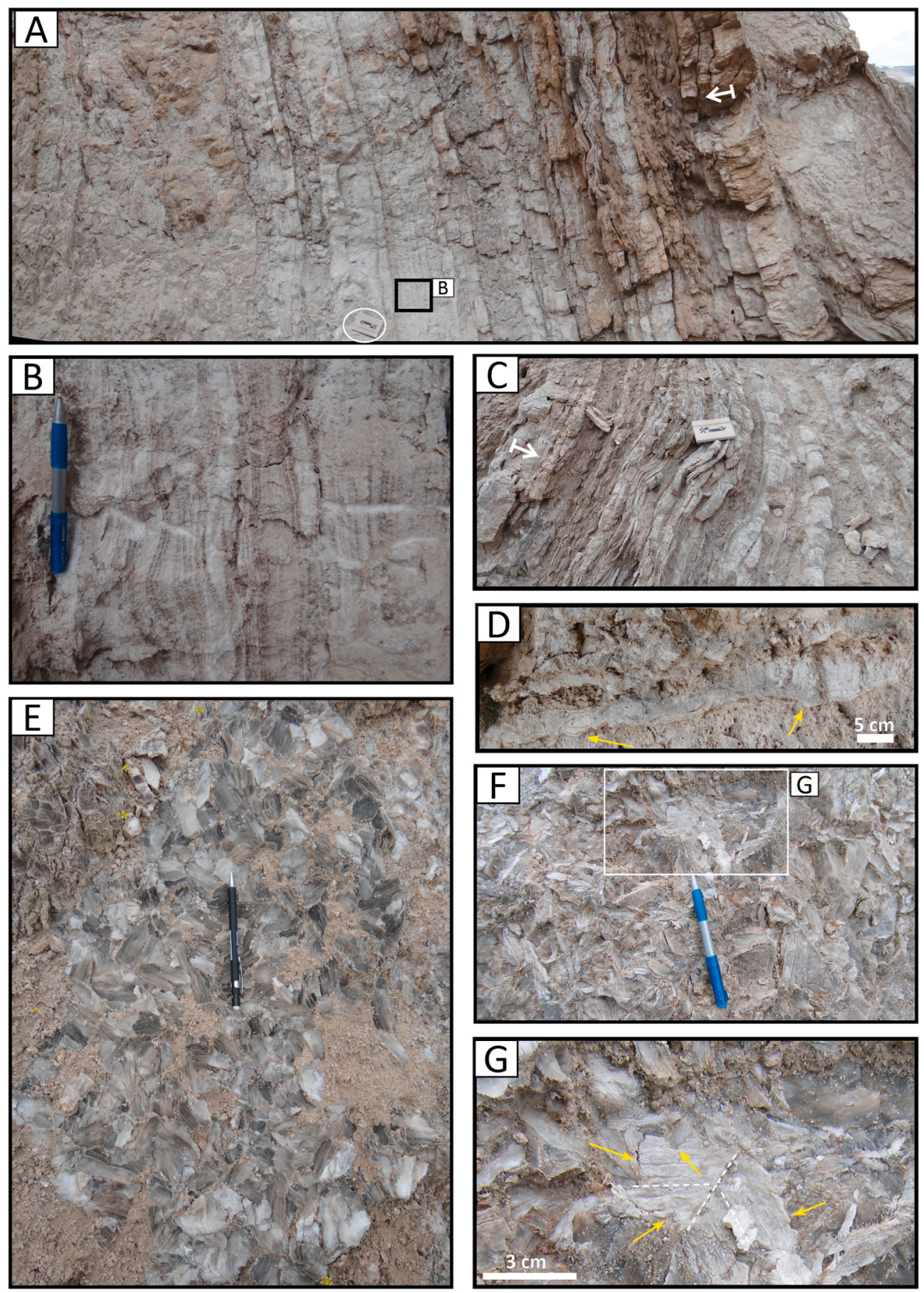

Fig. 16. A, B and C: Densely packed tabular beds of fine-grained to alabastrine gypsum interlayered by thin clay laminae. Note the thin wavy to parallel-laminations. D: Scours at the base of a fine-grained gypsum bed. E, F and G: Aggregate of coarse crystalline gypsum. Note the absence of any preferred orientation of the crystals. One gypsum crystal on pictures F and G display a twin plane. Note sutured contacts with surrounding crystals (yellow arrows). 
grains may also have been carried from the shoreline by wind processes and settled on the basin floor (Raup and Hite, 1992). By analogy with dolomitic muds reported during the Messinian salinity crisis, part of the dolomite content in this facies may be of diagenetic origin and result from sulphate-reduction processes in deepwater anoxic condition (e.g. de Lange et al., 2010; Sabino et al., 2020). Part of the gypsum probably also grown displacively in the mud through saline fluid-flow during burial and/or exhumation (e.g. Aref et al., 1997; Marsaglia and Tribble, 1999).

\section{GF2, mixed cumulate/reworked gypsiferous deposits}

This facies displays stacked tabular to slightly undulating gypsum beds, few millimeters to several centimeters-thick, thinly interlayered with millimeter-thick brown clayey layers (Fig. 16 A, B and C). The gypsum is free of detrital grains and only shows thin plane-parallel laminations (Fig. 16 B and C) and scarce scours (Fig. 16 D).

The small-scale clay-gypsum alternation are interpreted to record cumulate deposits that settled as a pelagic rain (e.g. Kirkland et al., 2000). The gypsum beds reaching thicknesses of several centimeters and displaying scours and parallel lamination are rather interpreted as sheet-like gypsarenites deposited by low-density currents (R5). Accordingly, we interpret this facies as recording cumulate gypsum rain closely interlayered with fine gypsarenite produced by diluted turbidity currents (e.g. Manzi et al., 2012; Karakitsios et al., 2016). The wavy laminations may result from anhydritization and rehydration processes, or, more probably, from buckling processes due to tectonic folding (e.g. Kirkland and Anderson, 1970).

\subsubsection{GF3, diagenetic secondary crystalline gypsum}

This facies displays a meshwork of unoriented few millimeters to 20 cm-long prismatic gypsum crystals (Fig. $16 \mathrm{E}$ ). The crystals are single or, more rarely twinned along the (100) plane (swallow-tail twin) forming a dense packing marked by sutured contacts between the crystals (Fig. 16 F and G) or, alternatively, enclosed in a friable shaly matrix (Fig. 17 A). An apparent bedding is locally highlighted within the crystalline mass
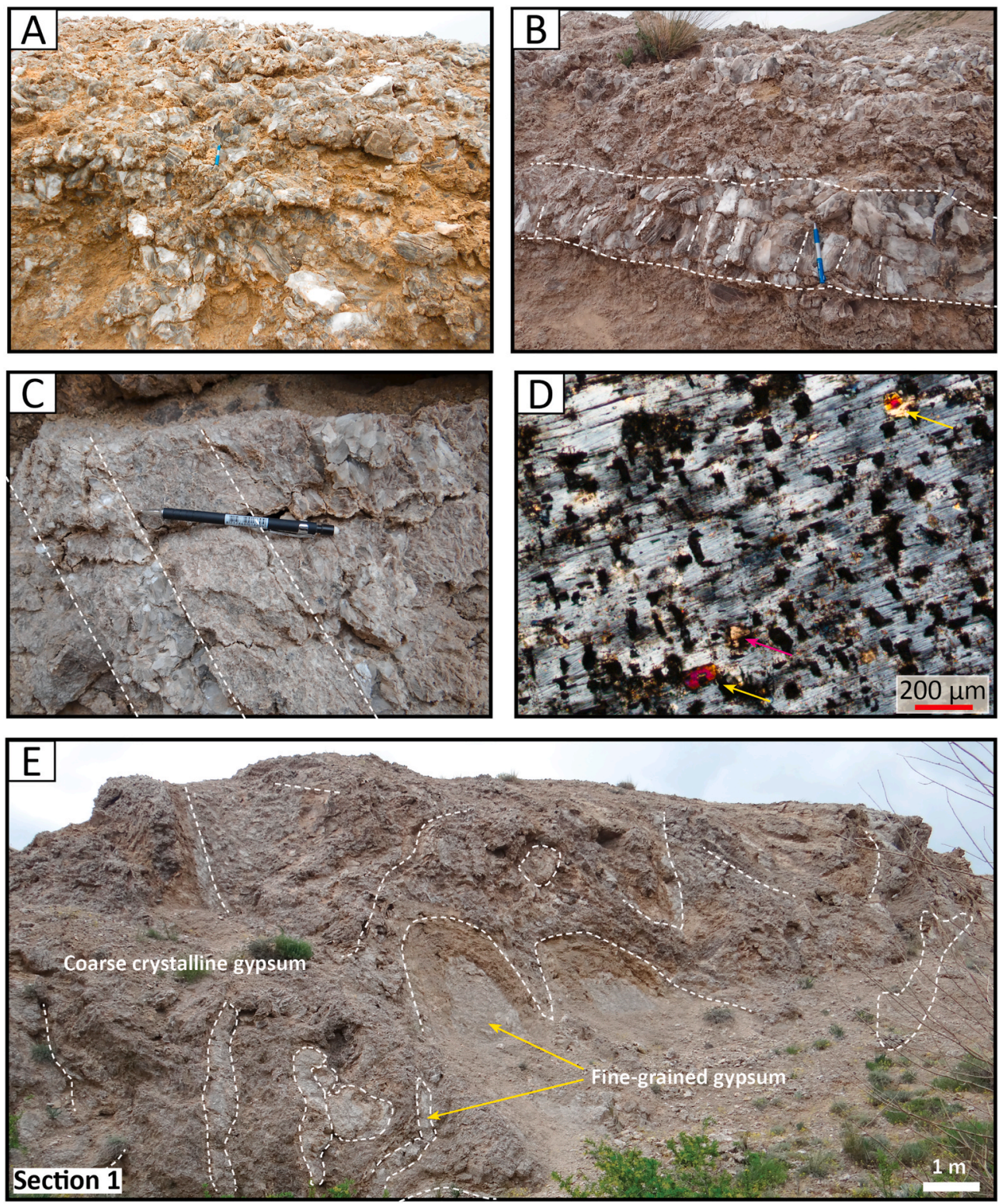

Fig. 17. A: Macro-crystalline gypsum crystals embedded in a clayey matrix. B and C: Layer planes (white dots) highlighted by variations in size of the selenitic gypsum crystals. D: Anhydrite and calcite inclusions in a coarse selenitic gypsum crystal (yellow and pink arrows respectively). E: Folded coarse crystalline gypsum mass enclosing boudins of fine-grained gypsum (white dots). 
by centimetre-to decimetre-thick layers of variable crystal size which are sometimes vertically oriented (Fig. $17 \mathrm{~B}$ and $\mathrm{C}$ ). In thin section, the crystals enclose tiny inclusions (usually $<200 \mu \mathrm{m}$ ) of (i) anhydrite (ii) calcite crystals, (iii) micrite grains and (iv) euhedral to subhedral gypsum crystals (Fig. 17 D). The chaotic crystalline mass also encloses folded and sheared beds, boudins and/or blocks of carbonates and secondary massive to fine-grained gypsum (Fig. 17 E) in which diagenetic transformation and tectonic deformations erased any primary textures (Fig. 18 A). The contact between the prismatic crystals and the underlying gypsum beds is sharp and concordant, or folded as a result of local tectonic folds (Fig. 18 B and C). In both cases, the crystalline mass locally (i) truncates the underlying beds as an erosive surface, (ii) encloses clasts from the underlying beds, (iii) forms spine-like shapes that penetrate the underlying beds and (iv) forms isolated patches that seems to have directly nucleated in the underlying beds (Fig. 18 B and C).

The chaotic orientation of the gypsum crystals, the almost total absence of swallow-tail habitus and the anhydrite inclusions suggest this facies is not a primary one (e.g. Babel, 2004; Ortí, 2011) but rather results from the hydration of anhydrite rocks (Lugli, 2001; Jaworska, 2012; Jaworska and Wilkosz, 2012; Jaworska and Nowak, 2013). A preserved primary selenitic texture is also unlikely, considering (i) the scarcity of swallow-tail twin habitus and (ii) the diagenetic transformations that must have affected the evaporite during burial. Similar, macro-crystalline textures have been described in the residual cap-rock of salt diapirs in Poland (Jaworska and Wilkosz, 2012) and in Italy (Lugli, 2001). In these settings, the gypsum crystals have grown at shallow depth, in the phreatic zone, from the hydration of anhydrite grains left as a residual phase after the leaching of diapiric halite. By analogy, we suggest that GF3 formed through the dissolution of significant accumulation of former halite deposits.

The bedding locally marked by different size of the gypsum crystals could result from repeated events of halite dissolution/anhydrite hydration, with different growth rate of the secondary gypsum. Alternatively, the space available for gypsum growth at the top of the halitedissolution front might have influenced the size of the crystals (similar to calcite cap-rocks observed in some diapiric stems; Posey et al., 1987). Following this hypothesis, the prismatic crystals could even have grown in a vertical position when the available space was high enough. Between the crystalline mass and the underlying gypsum beds, the truncating and deformed contacts probably results from the displacive growth of the secondary gypsum crystals. The coalescence of the displacive crystals would have locally enabled some bed fragments to be isolated in the crystalline mass, such as observed in Fig. 18 B. Shortening strain and folding of the Tuzhisar Formation must have enhanced the deformation of such contact, as observed in Fig. 18 C. Boudins and blocks of gypsum and carbonate embedded in the crystalline mass most probably characterize deposits that were initially interlayered in the halite. Such facies were collapsed, brecciated and folded by the progressive dissolution of halite before being incorporated in the residual gypsum crystalline mass (e.g. Lugli, 2001). Accordingly, the facies GF3 is interpreted as the evidence of a former thick halite accumulation.
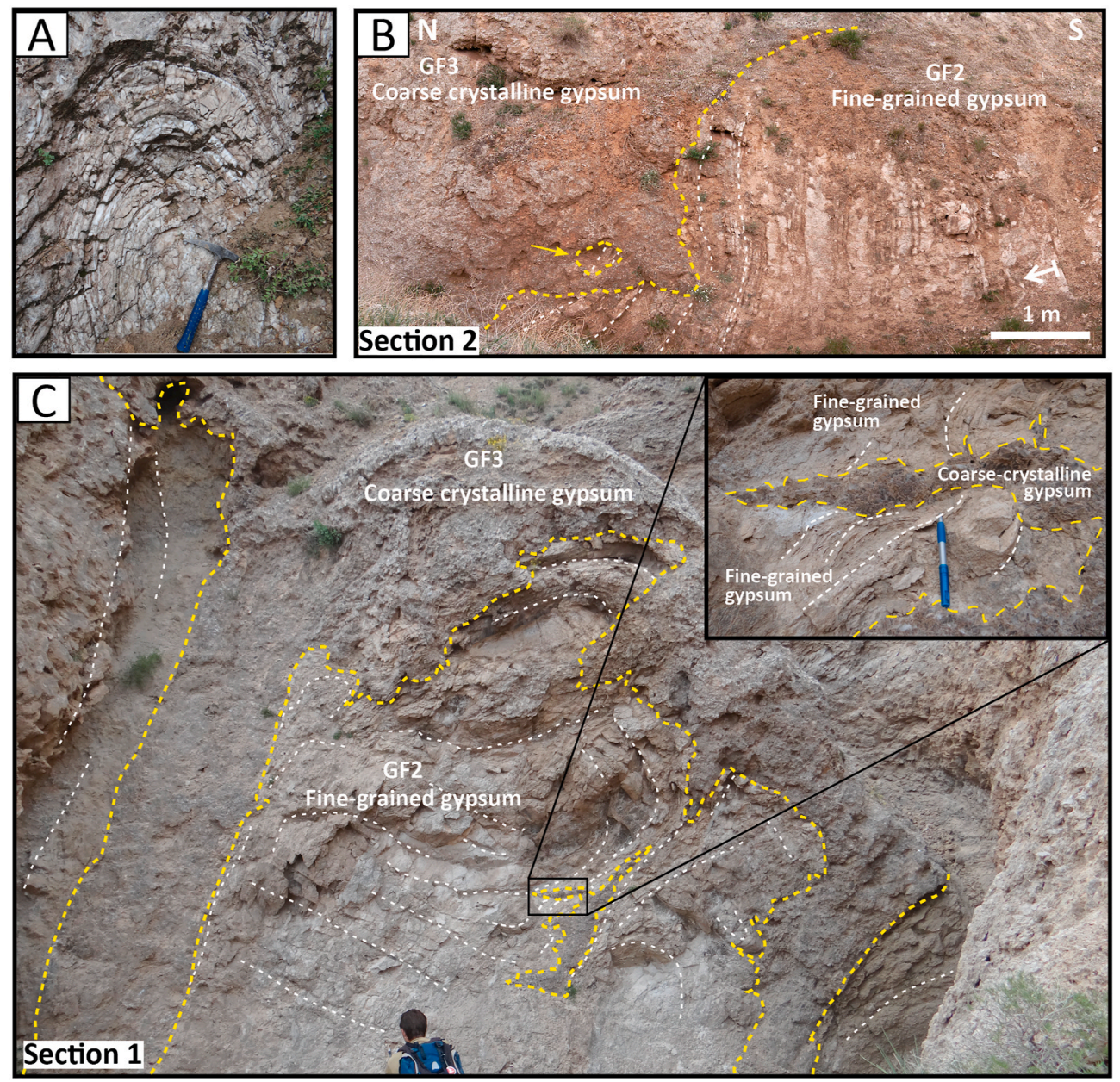

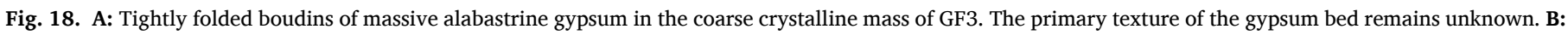

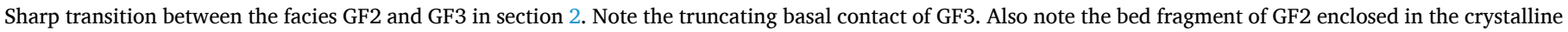
gypsum (yellow arrow) and displaying the same bed orientation than the underlying facies. C: Folded and displacive contact between the facies GF2 and GF3. 


\subsection{Facies associations}

The gypsiferous facies of the Tuzhisar Formation previously discussed can be grouped in three main facies associations (FA4 to 6).

m. FA4: Proximal high density siliciclastic-rich gypsiferous deposits

This FA groups the gypsiferous mass transport deposits (GT2) and the bed alternation of shale deposits with the high density gypsiferous and siliciclastic-rich turbiditic beds types (GT1, Fig. 6 B). This FA is interpreted as recording proximal poorly evolved gravity collapse deposits. According to the presence of Eocene, Cretaceous and ophiolitic exotic blocks embedded in the slumped interval, the gypsum-rich turbidites and the mass-transport deposit necessarily originated from the fold-andthrust-belt located farther south (Cater et al., 1991; Guezou et al., 1996; Legeay et al., 2019a). Accordingly, the FA4 probably records the dismantlement of shallow-water gypsum deposits formerly precipitated in a nearby thrust-top evaporitic basin along the southern highs of the


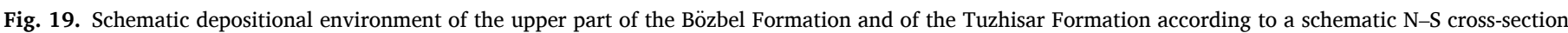

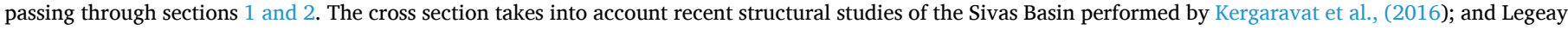
et al., (2019b, 2020). See the text for detailed explanations. 
Sivas margin, above an ophiolitic to Cretaceous basement.

\section{n. FA5: Siliciclastic-poor gypsiferous lobe deposits}

This facies association includes the bed alternation of gypsiferous shales (GF1) with the high to low density gypsiferous and siliciclasticpoor turbiditic bed types (GT3 and 4, Fig. $6 \mathrm{C}$ and D). This FA is interpreted as characterizing the accumulation of gypsiferous lobe deposits formed from the dismantlement of former primary evaporitic deposits and having accumulated in a more distal position than the FA1. In this FA, the lack of desiccation features, paleosols, sabkha-like facies or wave ripples, suggest relatively deep depositional setting (e.g. Lugli et al., 2015).

\section{o. FA6: Primary evaporitic deposits}

This FA includes the pelagic to reworked GF2 with the overlying diagenetic crystalline mass of facies GF3 recording the former occurrence of halite deposits (Fig. 6 D). This FA is interpreted as characterizing a saline basin having successively become oversaturated with respect to gypsum and halite due to increasing salinity conditions. The rafted gypsum and carbonate beds carried in the remaining crystalline mass of facies GF3 probably record former freshening events in the hypersaline basin due to marine or fresh-water entrance.

\section{Discussion: proposed regional correlations and depositional model}

As bed by bed correlations between the different sections are not possible, and because of the lack of relevant chronological markers, it is not possible to propose a robust correlation between the three sections. We thus propose hereafter an attempt of correlations based only on the facies associations evolution (Fig. 5) and considering the relatively short distance separating section 1 and 2 ( $\sim 8 \mathrm{~km}$ before shortening). These correlations enable to propose a three steps evolution of the foreland basin relating the setting up of a salinity crisis having resulted in thick accumulation of evaporites in the overall Sivas Basin. It is illustrated on Fig. 19 along a north to south cross-section involving sections 1 and 2.

\subsection{Step 1: Tectonic to eustatic confinement of the foreland basin}

sections 1 and 3 (Fig. 5) share a similar stratigraphic evolution where prodelta to delta-front deposits (Facies FA1 and FA2) display decreasing siliciclastic influxes, and grade to an anoxic sediment-starved and confined environment (FA3) before the first occurrence of gypsiferous turbidite lobes (FA5). A lithostratigraphic correlation is thus established between sections 1 and 3 up to the base of the Tuzhisar Formation. The confinement and stratification of the basin most probably resulted at first order from decreasing marine water inputs due to (i) a drop of the eustatic level and/or (ii) a tectonic uplift, both inducing the closure of the foreland along its eastern and/or western border(s) (e.g. Raup and Hite, 1992; Peryt, 2006). Long-term eustatic trends published for the Paleogene support the marine regression hypothesis during the Late Eocene (see Plyusnina et al., 2016 and reference therein). Coevally, the decrease of the siliciclastic influxes probably resulted from the tectonically induced modifications of the fluvial drainage network in the source area (Bentham and Burkbank, 1996) and/or of the turbidity current pathway in the uplifting basin trough (e.g. Roveri et al., 2003). The establishment of arid conditions might have contributed to the starving conditions recorded from the FA2 to the FA3 due to the progressive desiccation of river streams. Coeval dry climate together with decreasing sediment influxes have recently been evidenced in Eastern Turkey (Rego et al., 2018). Despite increasing aridity, continental runoffs carrying very fine-grained material were maintained in FA3 and probably contributed to intensify the water-column stratification and related bottom anoxic-conditions (e.g. Sabino et al., 2020).
To the south of the basin, section 2 does not record a decreasing amount of the clastic input as observed in sections 1 and 3; the basal turbidites of FA2 rather grades to high density gypsum-rich siliciclastic turbidites followed by a large gravitational collapse capped by gypsum debris flows (FA4). These high-density gravitational deposits are then capped by the siliciclastic-poor gypsiferous lobes also observed in sections 1 and 3 (FA5, Fig. 5). Once again, the conjunction of increasing aridity conditions together with (i) a progressive drop of the eustatic level and/or (ii) a tectonic uplift of the southern fold-and-thrust belt, might have allowed evaporite precipitation on the thrust-top basin margin, followed by their reworking, gravitational collapse and resedimentation in the foredeep during thrust propagation (e.g. Manzi et al., 2005; Anton et al., 2008; Roveri et al., 2008; Bache et al., 2015; Karakitsios et al., 2016).

Despite different facies assemblages between the southern section 2 and the northern sections 1 and 3, the stratigraphic evolution records thus the same climatic, tectonic and/or eustatic changes. However, the question that arises is how we can correlate the different facies evolutions? We hereafter propose two scenarii:

Scenario 1: The occurrence of gypsiferous turbiditic deposits are coeval in the north and in the south. Accordingly, the base of FA4 in section 2 is correlated with the base of FA5 in sections 1 and 3 (Fig. 5, scenario 1 ). If so, sections 1 and 3 recorded progressive starving conditions (FA2 to FA3), while siliciclastic influxes were maintained southward (FA2, Fig. 19 B1). Moreover, the gypsiferous turbidites of FA5 of section 1 and 3 could be the distal equivalent of the proximal coarse-grained gypsiferous turbidites of FA4 in section 2 (Fig. 19 C).

Scenario 2: The high density gypsiferous turbitides in section 2 (FA4) are coeval with the starving conditions in section 1 and 3 (Fig. 5, scenario 2) but remained confined in the southern foredeep (Fig. 19 B2). Following this scenario, the scarce gypsum bearing sandstones reported in the FA2 of sections 1 and 3 may record limited gypsiferous detrital influxes coming from the south.

Whatever the good correlative scenario, the lack of similar facies evolution between the south and the north most probably results from the existence of an anticline fold propagating in the foredeep, and forcing the confinement of the southern domain from the northern one, such as the last siliciclastic turbidites and/or the following gypsiferous turbidites remained confined in the southern foredeep area (e.g. Roveri et al., 2003; Sinclair and Tomasso, 2002). This situation was probably exacerbated by the fact that the turbidity currents were E-W oriented along the foredeep (Artan and Sestini, 1971; Cater et al., 1991). Finally, the influence of an anticline fold in the sedimentation pattern is supported by the numerous bidirectional current-ripples and hummocky cross-stratifications only observed in the FA2 and FA4 of section 2 and suggesting reflected currents on a topographic high.

\subsection{Step 2: Accumulation of gypsiferous turbiditic lobes}

The muddy sediments of FA3 in sections 1 and 3, and the last masstransported deposit in section 2, are followed by the same accumulations of coarse-to fine-grained gypsiferous turbidite lobes interbedded with detrital to chemical mudrocks (FA5) (Fig. 5). Despite the recognition of the tectonic duplication in section 1 (Fig. 4), only rough bed correlations could be performed between the two duplicates of FA5 (see Supplementary material 5). Proposing relevant bed correlations from one section to the other also revealed impossible. This suggests a high lateral facies variation of the gypsiferous turbidite lobes. However, sections 1 and 2 share a thin stratigraphic interval marked by the reestablishment of carbonate- and organic-rich deposits belonging to the FA3. Such interval probably records a coeval period during which resedimentation events were highly reduced and the basin became again starved with anoxic bottom water conditions, possibly because of a freshening event (increasing marine or meteoric water inputs; e.g. Sabino et al., 2020; Dela Pierre et al., 2014).

Following the previous interpretations of FA4, the gypsum turbidites 
of FA5 were probably fed by the ongoing dismantlement of the evaporitic sub-basin formerly developed in the fold-and-thrust belt located to the south of the foreland basin. Alternatively, the reworked evaporites of FA5 could have also been sourced by the dismantlement of gypsiferous platforms developing on the shallow-water northern shorelines of the basin (Fig. 19 C). Similar scenarios of evaporitic platform sourcing gypsum turbidites have already been proposed in other saline basins, such as in the Carpathian Foredeep (Peryt and Kasprzyk, 1992; Peryt, 2000), the Red Sea (Rouchy and Sommers, 1995), the European Zechstein Basin (Schlager and Bolz, 1977) or in the South-eastern Pyrenean Basin (Carrillo et al., 2014). The reworking of such an evaporitic platforms could have been triggered by (i) fluvial flooding events (explaining also the occurrence of siliciclastic contents; e.g. Hardie and Lowenstein, 2004), (ii) gravitational collapsing events of the platform-edge (e.g. Peryt and Kasprzyk, 1992; Carrillo et al., 2014) or (iii) erosion of exhuming evaporitic platforms due to water level fall and/or tectonic uplift (e.g. Manzi et al., 2005; Bache et al., 2015).

\subsection{Step 3: Hypersaline, gypsum to halite-saturated foreland basin}

In their upper part, sections 1 and 2 share the FA6 characterized by cumulates of gypsum (GF2) grading upward to the coarse crystalline secondary gypsum marking former halite accumulations (GF3). Compared to the previous deposits of FA5, the occurrence of FA6 highlights progressive increasing salinity conditions having probably resulted from increased evaporation and/or lesser freshwater water input. If precipitated in the same water body, these two saturation stages were necessarily coeval over the foredeep (Warren, 2016) and can thus be confidently correlated in sections 1 and 2 (Figs. 5 and $19 \mathrm{D}$ and E). Late Eocene marine geochemical signatures reported by Pichat et al. (2018) in the gypsiferous beds suggest that most of the ions requested to feed the evaporite precipitation were brought by marine seepages. Accordingly, the FA6 of the Tuzhisar Formation characterize a marine-fed gypsum-to halite-saturated foreland basin, restricted in surface marine input and affected by strong evaporative conditions. Because of dissolution, the thickness of halite deposited at the end of the Tuzhisar formation remains unknown. However, the halokinetic structures occurring in the Oligo-Miocene deposits of the Sivas Basin (Ribes et al., 2015; Kergaravat et al., 2016; Pichat et al., 2019) are similar to those described in basins where primary halite thicknesses were several hundred meters-to kilometers-thick (e.g. in the La Popa Basin, Utah (Williams-Stroud, 1994; Kluth and Du Chene, 2009), in the Central European Basin (Van der Baan, 1990; Mohr et al., 2005); in the Precaspian Basin, Kazakhstan (Volozh et al., 2003) or in the Gulf of Mexico (Reed, 1994; Callot et al., 2016). By analogy, similar thicknesses of halite must have been deposited in the Sivas Basin. Considering the fast sedimentation rate for halite to precipitate (up to several tens of centimeters per year, Schreiber and Hsü, 1980; Manzi et al., 2012; Sirota et al., 2017), such large accumulations required several hundred meters of accommodation space to be available. The presence of a deep tectonic depression in the foreland before evaporite precipitation has probably provided a high accommodation space for halite precipitation. Moreover, a significant part of the space needed for evaporite accumulation might have been provided during evaporite sedimentation by a fast subsidence rate of the foredeep, which can be as high as $500 \mathrm{~m} / \mathrm{Ma}$ (Vergés et al., 1998). This flexural subsidence could have been promoted by the loading (i) of the growing southern fold-and-thrust belt, and (ii) of the evaporitic deposition that enabled a rapid isostatic compensation (van den Belt and de Boer, 2007).

\section{Conclusion}

We performed a sedimentological study in the marine to evaporitic Late Eocene deposits of the central part of the Sivas foreland basin (Turkey). The study is based on three cross-sections, starting in the marine siliciclastic deposits of the top of the Bözbel Formation, and ending in the gypsiferous deposits of the Tuzhisar Formation. Our observations and interpretations enabled us to propose a tectonostratigraphic evolution of the foreland which can be summarized as follow:

1) The last deposits of the Bözbel Formation record pro-delta to delta front flood-generated turbidites. In the central part of the basin, the siliciclastic turbidites progressively vanishes, the basin becomes increasingly sediment-starved and evolves toward azoic calcareous and muddy facies interlayered with organic-rich shales. Such evolution highlight (i) a progressive confinement from the oceanic domain coupled with (ii) an increase of aridity and (iii) tectonicallyinduced modifications of the fluvial and turbiditic networks.

2) The southern part of the basin, corresponding to the central foredeep, was relatively confined from the northern one, likely due to the development of an anticlinal fold. There, the turbidites of the Bözbel Formation become increasingly gypsum-rich and recorded a megaslump enclosing olistolites of gypsum and of ophiolitic rocks. Such reworked evaporites were fed by the gravitational collapse of shallow water evaporites previously deposited in thrust-top piggyback basins, along the fold-and-thrust-belt located to the south of the Sivas basin. The shortening that led to evaporite dismantlement also contributed to the closure of the basin from the marine domain.

3) From the north to the south, subsequent deposits of the Tuzhisar Formation consist in about $70 \mathrm{~m}$ of high-to low-density gypsum turbiditic lobes accumulated in a relatively deep-water setting. Such deposits could be sourced from (i) the southern fold-and-thrust belt or (ii) evaporitic platforms coevally developed along the shallowwater borders of the gypsum-saturated basin.

4) The reworked evaporites are finally extensively sealed by a thick $(>100 \mathrm{~m})$ chaotic and coarse crystalline gypsum mass carrying folded rafts and boudins of carbonate and gypsum beds. Such unit is interpreted as a crystalline caprock formed through the hydration of anhydrite grains left as a residual phase after the leaching of significant accumulations of halite. The latter probably precipitated in a perennial hypersaline basin fed in solutes by marine seepages. This halite was responsible for mini-basin development and salt tectonics during the Oligo-Miocene farther north in the basin.

Finally, this work is a first attempt to characterize the salinity crisis that affected the Sivas Basin in its central part during the Late Eocene. Further sedimentological and structural investigations in the Sivas Basin will be necessary to refine our proposed depositional model. However, this work documents thick and widespread accumulations of reworked gypsiferous deposits, which might improve the comprehension of comparable deposits accumulated at the same period over the Central Anatolian basins, or in similar geological settings elsewhere in the world (e.g. in the South Pyrenean basins).

\section{Declaration of competing interest}

The authors declare that they have no known competing financial interests or personal relationships that could have appeared to influence the work reported in this paper.

\section{Acknowledgment}

The authors thank Total SE for their financial support. We are grateful to S. K. Kavak, G. Calinak and G. Dinc for their precious assistance during the field work. E. Legeay is also kindly thanked for his help on the field. M. Rovery, S. Lugli and V. Manzi are warmly thanked for valuable discussions on several aspects of this manuscript. We finally warmly thanks Roberto Tinterri and one anonymous reviewer who greatly contributed to improve the writing of the manuscript. 


\section{Appendix A. Supplementary data}

Supplementary data to this article can be found online at https://doi. org/10.1016/j.marpetgeo.2021.105151.

\section{References}

Aktimur, H.T., Tekirli, M.E., Yurdakul, M.E., 1990. Geology of the sivas-erzincan tertiary basin. Miner. Resour. Explor. Bull. 111, 21-30.

Altunsoy, M., Özçelik, O., 1998. Organic facies characteristics of the Sivas tertiary basin (Turkey). J. Petrol. Sci. Eng. 20, 73-85. https://doi.org/10.1016/S0920-4105(97) 00051-X.

Anton, J., Çagatay, M.N., De Lange, G., Flecker, R., Gaullier, V., Gunde-Cimerman, N., Hübscher, C. Krijgsman, W., Lambregts, P., Lofi, J., Lugli, S., Manzi, V., McGenity, T.J., Roveru, M., Sierro, F.J., Suc, J.-P., 2008. Executive summary. In: Briand, F. (Ed.), The Messinian Salinity Crisis from Mega-Deposits to Microbiology a Consensus Report. CIESM Workshop Monographs, Monaco, pp. 7-28.

Aref, M.A.M., Attia, O.E.A., Wali, A.M.A., 1997. Facies and depositional environment of the holocene evaporites in the ras shukeir area, Gulf of suez. Egypt. Sediment. Geol. 110, 123-145. https://doi.org/10.1016/S0037-0738(96)00080-2.

Arikan, Y., 1975. The geology and petroleum prospects of the Tuz Gölü Basin. MTA Bull. 85, 17-37.

Arnott, R.W.C., 2010. Deep-marine sediments and sedimentary systems. In: James, N.P. Dalrymple, R. (Eds.), Facies Models 4. Geological Association of Canada, pp. 295-322.

Artan, Ü., Sestini, G., 1971. Geology of the beypinari-karababa area (Sivas Province) Bull. Miner. Res. Explor. (Ankara, Turkey) 76, 72-89.

Bache, F., Gargani, J., Suc, J.P., Gorini, C., Rabineau, M., Popescu, S.M., Leroux, E., Couto, D., Do, Jouannic, G., Rubino, J.L., Olivet, J.L., Clauzon, G., Dos Reis, A.T., Aslanian, D., 2015. Messinian evaporite deposition during sea level rise in the Gulf of Lions (Western Mediterranean). Mar. Petrol. Geol. 66, 262-277. https://doi.org/ 10.1016/j.marpetgeo.2014.12.013.

Bentham, P., Burkbank, D.W., 1996. Chronology of Eocene foreland basin evolution along the western oblique margin of the South-Central Pyrenees. Tertiary Basins of Spain. In: Friend, P.F., Dabrio, C.J. (Eds.), vol. E11. Cambridge University Press World and Regional Geology, pp. 144-152.

Bhattacharya, J.P., MacEachern, J.A., 2009. Hyperpycnal rivers and prodeltaic shelves in the cretaceous seaway of north America. J. Sediment. Res. 79, 184-209. https://doi. $\operatorname{org} / 10.2110 /$ jsr.2009.026.

Booth, M.G., Robertson, A.H.F., Tasli, K., Inan, N., 2014. Late cretaceous to late Eocene hekimhan basin (central eastern Turkey) as a supra-ophiolite sedimentary/magmatic basin related to the later stages of closure of Neotethys. Tectonophysics $635,6-32$ https://doi.org/10.1016/j.tecto.2014.05.039.

Bourget, J., Zaragosi, S., Mulder, T., Schneider, J.L., Garlan, T., Van Toer, A., Mas, V., Ellouz-Zimmermann, N., 2010. Hyperpycnal-fed turbidite lobe architecture and recent sedimentary processes: a case study from the $\mathrm{Al}$ Batha turbidite system, Oman margin. Sediment. Geol. 229, 144-159. https://doi.org/10.1016/j. sedgeo.2009.03.009.

Babel, M., 2004. Badenian evaporite basin of the northern Carpathian Foredeep as a drawdown salina basin. Acta Geol. Pol. 54, 313-337. https://doi.org/10.1144/ SP285.13.

Callot, J.P., Ribes, C., Kergaravat, C., Bonnel, C., Temiz, H., Poisson, A., Vrielynck, B., Salel, J.F., Ringenbach, J.C., 2014. Salt tectonics in the Sivas basin (Turkey): crossing salt walls and minibasins. Bull. Soc. Geol. Fr. 185, 33-42. https://doi.org/ 10.2113/gssgfbull.185.1.33.

Callot, J.-P., Salel, J., Letouzey, J., Daniel, J., Mengus, J., Pillot, D., Ringenbach, J., 2016. Three-dimensional evolution of salt-controlled minibasins: interactions, folding, and megaflap development. Am. Assoc. Petrol. Geol. Bull. 100, 1419-1442.

Carrillo, E., Rosell, L., Ortí, F., 2014. Multiepisodic evaporite sedimentation as an indicator of palaeogeographical evolution in foreland basins (South-eastern Pyrenean basin, Early-Middle Eocene). Sedimentology 61, 2086-2112. https://doi. org $/ 10.1111 /$ sed.12140.

Cater, J.M.L., Hanna, S.S., Ries, A.C., Turner, P., 1991. Tertiary evolution of the Sivas basin, central Turkey. Tectonophysics 195, 29-46. https://doi.org/10.1016/00401951(91)90142-F.

Cemen, I., GöncUoglu, M.C., Dirik, K., 1999. Structural evolution of the Tuzgölü basin in central anatolia. Turkey. J. Geol. 107, 693-706.

Cheel, R., Leckie, D., 1993. Hummocky cross-stratification. In: Wright, V. (Ed.), Sedimentology Review. Blackwell Scientific Publications, pp. 103-122.

Clark, M., Robertson, A., 2005. Uppermost Cretaceous-Lower Tertiary Ulukisla Basin, south-central Turkey: sedimentary evolution of part of a unified basin complex within an evolving Neotethyan suture zone. Sediment. Geol. 173, 15-51. https://doi org /10.1016/j.sedgeo.2003.12.010.

Cobbold, P.R., Zanella, A., Rodrigues, N., Løseth, H., 2013. Bedding-parallel fibrous veins (beef and cone-in-cone): worldwide occurrence and possible significance in terms of fluid overpressure, hydrocarbon generation and mineralization. Mar. Petrol. Geol. 43, 1-20. https://doi.org/10.1016/j.marpetgeo.2013.01.010.

de Lange, G.J., Krijgsman, W., 2010. Messinian salinity crisis: a novel unifying shallow gypsum/deep dolomite formation mechanism. Mar. Geol. 275 (1-4), 273-277.

Decima, A., McKenzie, J.A., Schreiber, B.C., 1988. The origin of 'evaporative' limestones: an example from the Messinian of Sicily (Italy). J. Sediment. Petrol. 58, 256-272.

Dela Pierre, F., Clari, P., Natalicchio, M., Ferrando, S., Giustetto, R., Lozar, F., Lugli, S., Manzi, V., Roveri, M., Violanti, D., 2014. Flocculent layers and bacterial mats in the mudstone interbeds of the Primary Lower Gypsum unit (Tertiary Piedmont basin,
NW Italy): archives of palaeoenvironmental changes during the Messinian salinity crisis. Mar. Geol. 355, 71-87. https://doi.org/10.1016/j.margeo.2014.05.010.

Dilek, Y., Sandvol, E., 2009. Seismic structure, crustal architecture and tectonic evolution of the anatolian-african plate boundary and the cenozoic orogenic belts in the eastern mediterranean region. Geol. Soc. Lond. Spec. Publ. 327, 127-160. https:// doi.org/10.1144/SP327.8.

Elliott, L.A., Warren, J.K., 1989. Stratigraphy and depositional environment of lower San Andres formation in subsurface and equivalent outcrops: chaves, Lincoln, and Roosevelt Counties. New Mexico. Am. Assoc. Pet. Geol. Bull. 73, 1307-1325. https://doi.org/10.1306/44B4AA41-170A-11D7-8645000102C1865D.

Gee, M.J.R., Uy, H.S., Warren, J., Morley, C.K., Lambiase, J.J., 2007. The Brunei slide: a giant submarine landslide on the North West Borneo Margin revealed by 3D seismic data. Mar. Geol. 246, 9-23. https://doi.org/10.1016/j.margeo.2007.07.009.

Gindre-Chanu, L., Warren, J.K., Puigdefabregas, C., Sharp, I.R., Peacock, D.C.P., Swart, R., Poulsen, R., Ferreira, H., Henrique, L., 2015. Diagenetic evolution of aptian evaporites in the namibe basin (south-west Angola). Sedimentology 62, 204-233. https://doi.org/10.1111/sed.12146.

Görür, N., Tüysüz, O., Celal Şengör, a.M., 1998. Tectonic evolution of the central anatolian basins. Int. Geol. Rev. 40, 831-850. https://doi.org/10.1080/ 00206819809465241.

Guezou, J.-C., Temiz, H., Poisson, A., Gürsoy, H., 1996. Tectonics of the Sivas basin: the neogene record of the anatolian accretion along the inner tauric suture. Int. Geol. Rev. 38, 901-925. https://doi.org/10.1080/00206819709465371.

Guido, A., Jacob, J., Gautret, P., Laggoun-Defarge, F., Mastandrea, A., Russo, F., 2007. Molecular fossils and other organic markers as paleoenvironmental indicators of the messinian calcare di Base formation: normal versus stressed marine deposition (rossano basin, northern calabria, Italy): palaeogeography, palaeoclimatology, palaeoecology, pp. 265-283. https://doi.org/10.1016/j.palaeo.2007.07.015, v. 255.

Gündogan, I., Önal, M., Depçi, T., 2005. Sedimentology, petrography and diagenesis of eocene-oligocene evaporites: the Tuzhisar formation, SW Sivas basin, Turkey. J. Asian Earth Sci. 25, 791-803. https://doi.org/10.1016/j.jseaes.2004.08.002.

Gürbüz, K., Gül, M., 2005. Evolution of and factors controlling Eocene sedimentation in the darende-balaban basin, malatya (eastern Turkey). Turkish J. Earth Sci. 14, $311-335$.

Hakyemez, A., Özgen-Erdem, N., Kangal, Ö., 2016. Planktonic and benthic foraminiferal biostratigraphy of the Middle Eocene-Lower Miocene successions from the Sivas Basin (Central Anatolia, Turkey). Geol. Carpathica 67 (1), 21-40.

Hardie, L.A., Lowenstein, T.K., 2004. Did the Mediterranean sea dry out during the Miocene? A reassessment of the evaporite evidence from DSDP legs 13 and 42A cores. J. Sediment. Res. 74, 453-461. https://doi.org/10.1306/112003740453.

Harms, J., Southard, J.B., Spearing, D.R., Walker, R.G., 1975. Depositional environments as interpreted from primary sedimentary structures and stratification sequences. SEPM Short. Course 2, 161 .

Haughton, P.D., 1994. Deposits of deflected and ponded turbidity currents, Sorbas Basin, Southeast Spain. J. Sediment. Res. 64 (2a), 233-246.

Holliday, D.W., 1970. The petrology of secondary gypsum rocks: a review. J. Sediment. Petrol. 40, 734-744. https://doi.org/10.1306/74d7202c-2b21-11d7$8648000102 \mathrm{c} 1865 \mathrm{~d}$.

Hussain, M., Warren, J.K., 1989. Nodular and enterolithic gypsum: the "sabkha-tization" of Salt Flat playa, west Texas. Sediment. Geol. 64, 13-24. https://doi.org/10.1016/ 0037-0738(89)90081-X.

Huvaz, O., 2009. Comparative petroleum systems analysis of the interior basins of Turkey: implications for petroleum potential. Mar. Petrol. Geol. 26, 1656-1676. https://doi.org/10.1016/j.marpetgeo.2009.05.002.

Jaworska, J., 2012. Crystallization, alternation and recrystallization of sulphates. In: Mastai, Y. (Ed.), Intech 465-490. https://doi.org/10.5772/2672. Advances in Crystallization Processes.

Jaworska, J., Nowak, M., 2013. Anhydrites from gypsum cap-rock of Zechstein salt diapirs. Geol. Geophys. Environ 39, 233-250.

Jaworska, J., Wilkosz, P., 2012. Oxygen and sulphur isotopes of gypsum from the Mogilno Salt Dome cap-rock (Central Poland). Geol. Q. 56, 249-260. https://doi. org/10.7306/gq.1019.

Karakitsios, V., Roveri, M., Lugli, S., Manzi, V., Gennari, R., Antonarakou, A., Triantaphyllou, M., Agiadi, K., Kontakiotis, G., Kafousia, N., de Rafelis, M., 2016. A record of the Messinian salinity crisis in the eastern Ionian tectonically active domain (Greece, eastern Mediterranean). Basin Res. 1-31. https://doi.org/10.1111/ bre.12173.

Kasprzyk, A., 2003. Sedimentological and diagenetic patterns of anhydrite deposits in the Badenian evaporite basin of the Carpathian Foredeep, southern Poland. Sediment. Geol. 158, 167-194. https://doi.org/10.1016/S0037-0738(02)00265-8.

Kasprzyk, A., Orti, F., 1998. Palaeogeographic and burial controls on anhydrite genesis: the Badenian basin in the Carpathian Foredeep (southern Poland, western Ukraine). Sedimentology 45, 889-907. https://doi.org/10.1046/j.1365-3091.1998.00190.x.

Kaymakci, N., 2000. Tectono-stratigraphical Evolution of the Çankırı Basin (Central Anatolia, Turkey). PhD thesis. Universiteit Utrecht, Netherlands.

Kaymakci, N., Özmutlu, S., Dijk, P.M.V. a N., Özçelİk, Y., 2010. Surface and subsurface characteristics of the Çankırı Basin (Central Anatolia, Turkey): integration of remote sensing, seismic interpretation and gravity. Turk. J. Earth Sci. 19, 79-100. https:// doi.org/10.3906/yer-0807-3.

Kergaravat, C., 2016. Dynamique de formation et de déformation de mini-bassins en contexte compressif : approche terrain, implications structurales multi-échelles et réservoirs (exemple du bassin de Sivas, Turquie). Ph.D. Thesis. In: Université de Pau et des Pays de l'Adour. Pau, France.

Kergaravat, C., Ribes, C., Callot, J.-P., Legeay, E., Ringenbach, J.-C., 2016. Minibasins and salt canopies in foreland fold-and-thrust belts: the central Sivas Basin, Turkey. Tectonics 35, 1-57. https://doi.org/10.1002/2016TC004186. 
Kergaravat, C., Ribes, C., Callot, J.P., Ringenbach, J.C., 2017. Tectono-stratigraphic evolution of salt-controlled minibasins in a fold and thrust belt, the Oligo-Miocene central Sivas Basin. J. Struct. Geol. 102, 75-97.

Keskin, S., Şener, M., Şener, F.M., Öztürk, M.Z., 2017. Depositional environment characteristics of ulukışla evaporites, central anatolia, Turkey. Carbonates Evaporites 32, 231-241. https://doi.org/10.1007/s13146-016-0292-7.

Kirkland, D.W., Anderson, R.Y., 1970. Microfolding in the castile and todilto evaporites, Texas and New Mexico. Geol. Soc. Am. Bull. 81 (11), 3259-3282.

Kirkland, D.W., Denison, R.E., Dean, W.E., 2000. Parent brine of the castile evaporites (upper permian), Texas and New Mexico. J. Sediment. Res. 70 (3), 749-761.

Kluth, C.F., Du Chene, H.R., 2009. Late pennsylvanian and early permian structural geology and tectonic history of the paradox basin and uncompahgre uplift, Colorado and Utah. In: Houston, W.S., Wray, L.L., Moreland, P.G. (Eds.), The Paradox Basin Revisited - New Developments in Petroleum Systems and Basin Analysis ;: RMAG 2009 Special Publication - the Paradox Basin, pp. 178-197.

Kneller, B.C., Branney, M.J., 1995. Sustained high-density turbidity currents and the deposition of thick massive sands. Sedimentology 42 (4), 607-616.

Kurtman, F., 1973. Geologic and tectonic structure of the sivas-hafik-zara and imranl region. Bull. Miner. Res. Explor. (Ankara, Turkey) 80, 1-32.

Larmier, S., Zanella, A., Lejay, A., Mourgues, R., Gelin, F., 2021. Geological Parameters Controlling the Bedding-Parallel Vein Distribution in Vaca Muerta Formation Core Data. AAPG Bulletin, Neuquén Basin, Argentina. https://doi.org/10.1306/ 03122119201 (in press).

Legeay, E., 2017. Géodynamique du bassin de Sivas (Turquie) - de la fermeture d'un domaine océanique à la mise en place d'un avant-pays salifère. $\mathrm{PhD}$ thesis. In: Université de Pau et des Pays de l'Adour. France.

Legeay, E., Mohn, G., Ringenbach, J.-C., Callot, J.-P., Ulianov, A., Kavak, K.Ş., 2019a. The pre- to post-obduction evolution of the Sivas ophiolite (Central Anatolia, Turkey). Tectonics 36, 2114-2141. https://doi.org/10.1029/2018TC005114.

Legeay, E., Pichat, A., Kergaravat, C., Ribes, C., Callot, J.-P., Ringenbach, J.-C., 2019b. Geology of the central Sivas basin. J. Maps 15, 406-417.

Legeay, E., Ringenbach, J.C., Kergaravat, C., Pichat, A., Mohn, G., Vergés, J., Kavak, K.Ş. Callot, J.P., 2020. Structure and Kinematics of the Central Sivas Basin (Turkey): Salt Deposition and Tectonics in an Evolving Fold-And-Thrust Belt, vol. 490. Geological Society, London, Special Publications, pp. 361-396, 1.

Lowe, D.R., 1982. Sediment gravity flows; II, Depositional models with special reference to the deposits of high-density turbidity currents. J. Sediment. Res. 52 (1), 279-297.

Lugli, S., 2001. Timing of post-depositional events in the Burano Formation of the Secchia valley (Upper Triassic, Northern Apennines), clues from gypsum-anhydrite transitions and carbonate metasomatism. Sediment. Geol. 140, 107-122. https:// doi.org/10.1016/S0037-0738(00)00174-3.

Lugli, S., Gennari, R., Gvirtzman, Z., Manzi, V., Roveri, M., Schreiber, B.C., 2013. Evidence of clastic evaporites in the canyons of the levant basin (Israel): implications for the messinian salinity crisis. J. Sediment. Res. 83, 942-954. https://doi.org/ 10.2110/jsr.2013.72.

Lugli, S., Manzi, V., Roveri, M., Schreiber, B.C., 2015. The deep record of the Messinian salinity crisis: evidence of a non-desiccated Mediterranean Sea. Palaeogeogr. Palaeoclimatol. Palaeoecol 433, 201-218. https://doi.org/10.1016/j. palaeo.2015.05.017.

Manzi, V., Lugli, S., Lucchi, F.R., Roveri, M., 2005. Deep-water clastic evaporites deposition in the Messinian Adriatic foredeep (northern Apennines, Italy): did the Mediterranean ever dry out? Sedimentology 52, 875-902. https://doi.org/10.1111/ j.1365-3091.2005.00722.x

Manzi, V., Lugli, S., Roveri, M., Schreiber, B.C., Gennari, R., 2011. The messinian "calcare di Base" (sicily, Italy) revisited. Geol. Soc. Am. Bull. 123, 347-370.

Manzi, V., Gennari, R., Lugli, S., Roveri, M., Scafetta, N., Schreiber, B.C., 2012. Highfrequency cyclicity in the mediterranean messinian evaporites: evidence for solarlunar climate forcing. J. Sediment. Res. 82, 991-1005. https://doi.org/10.2110/ jsr.2012.81.

Marsaglia, K.M., Tribble, J.S., 1999. Petrography and mineralogy of the uppermost Messinian section and the Pliocene/Miocene boundary at site 975, western Mediterranean Sea. In: Zahn, R., Comas, M.C., Klaus, A. (Eds.), Proceedings of the Ocean Drilling Program, , Eds.vol. 161. Scientific Results, pp. 3-20.

Mohr, M., Kukla, P.a., Urai, J.L., Bresser, G., 2005. Multiphase salt tectonic evolution in NW Germany: seismic interpretation and retro-deformation. Int. J. Earth Sci. 94, 917-940. https://doi.org/10.1007/s00531-005-0039-5.

Mohrig, D., Marr, J.G., 2003. Constraining the efficiency of turbidity current generation from submarine debris flows and slides using laboratory experiments. Mar. Petrol. Geol. 20 (6-8), 883-899.

Mulder, T., Syvitski, J.P.M., Migeon, S., Faugères, J.C., Savoye, B., 2003. Marine hyperpycnal flows: initiation, behavior and related deposits. A review. Mar. Petrol. Geol. 20, 861-882. https://doi.org/10.1016/j.marpetgeo.2003.01.003.

Murray, R., 1964. Origin and diagenesis of gypsum and anhydrite. J. Sediment. Res. 34 512-523.

Mutti, E., 1977. Distinctive thin-bedded turbidites facies and related depositional environments in the Eocene Hecho Group (South-central Pyrenees, Spain). Sedimentology 24, 107-131.

Mutti, E., Tinterri, R., Remacha, E., Mavilla, N., Angella, S., Fava, L., 1999. An Introduction to the Analysis of Ancient Turbidite Basins from an Outcrop Perspective. The American Association of Petroleum Geologists. Oklahoma, U. S. A, Tulsa.

Mutti, E., Lucchi, F.R., Roveri, M., 2002. Revisiting turbidites of the Marnoso-arenacea formation and their basin-margin equivalents: problems with classic models, Excursion guidebook of the turbidite workshop. In: 64th EAGE Conference and Exhibition. Italy, Florence.
Mutti, E., Tinterri, R., Benevelli, G., Biase, D. di, Cavanna, G., 2003. Deltaic, mixed and turbidite sedimentation of ancient foreland basins. Mar. Petrol. Geol. 20, 733-755. https://doi.org/10.1016/j.marpetgeo.2003.09.001.

Mutti, E., Bernoulli, D., Lucchi, F.R., Tinterri, R., 2009. Turbidites and turbidity currents from alpine "flysch" to the exploration of continental margins. Sedimentology 56, 267-318. https://doi.org/10.1111/j.1365-3091.2008.01019.x.

Muzzi Magalhaes, P., Tinterri, R., 2010. Stratigraphy and depositional setting of slurry and contained (reflected) beds in the marnoso-arenacea formation (langhian serravallian) northern apennines, Italy. Sedimentology 57, 1685-1720. https://doi. org/10.1111/j.1365-3091.2010.01160.x.

Nairn, S.P., Robertson, A.H.F., Unlugenc, U.C., Tasli, K., Inan, N., 2012. Tectonostratigraphic evolution of the Upper Cretaceous-Cenozoic central Anatolian basins: an integrated study of diachronous ocean basin closure and continental collision. Geol. Soc. Lond. Spec. Publ. 372, 343-384. https://doi.org/10.1144/ SP372.9.

Ogata, K., Mutti, E., Pini, G.A., Tinterri, R., 2012. Mass transport-related stratal disruption within sedimentary mélanges: examples from the northern Apennines (Italy) and south-central Pyrenees (Spain). Tectonophysics 568-569, 185-199. https://doi.org/10.1016/j.tecto.2011.08.021.

Okay, A.I., Tüysüz, O., Satir, M., Ozcan-Altiner, S., Altiner, D., Sherlock, S., Eren, R.H., 2006. Cretaceous and Triassic subduction-accretion, high-pressure-low-temperature metamorphism, and continental growth in the Central Pontides. Turkey. Geol. Soc. Am. Bull. 118, 1247-1269.

Ortí, F., 2011. Selenite facies in marine evaporites: a review. Special Publ. Int. Assoc. Sedimentol. 43, 431-464.

Özçelik, O., Altunsoy, M., 1996. Clastic petrofacies, provenance and organic facies of the Bozbel formation (lutetian) in the eastern Sivas basin (Turkey). Mar. Petrol. Geol. 13, 493-501. https://doi.org/10.1016/0264-8172(96)00006-2.

Peryt, T., 2000. Resedimentation of basin centre sulphate deposits: middle Miocene badenian of carpathian foredeep, southern Poland. Sediment. Geol. 134, 331-342. https://doi.org/10.1016/S0037-0738(00)00056-7.

Peryt, T.M., 2006. The Beginning, Development and Termination of the Middle Miocene Badenian Salinity Crisis in Central Paratethys, vol. 189, pp. 379-396. https://doi. org/10.1016/j.sedgeo.2006.03.014.

Peryt, T.M., Jasionowski, M., 1994. In situ formed and redeposited gypsum breccias in the Middle Miocene Badenian of southern Poland. Sediment. Geol. 94, 153-163. https://doi.org/10.1016/0037-0738(94)90152-X.

Peryt, T.M., Kasprzyk, A., 1992. Earthquake-induced resedimentation in the Badenian (middle Miocene) gypsum of southern Poland. Sedimentology 39, 235-249 doi.

Pichat, A., Hoareau, G., Callot, J.-P., Legeay, E., Kavak, K.S., Révillon, S., Parat, C., Ringenbach, J.-C., 2018. Evidence of multiple evaporite recycling processes in a salttectonic context, Sivas Basin. Turkey. Terra Nov. 30, 40-49. https://doi.org/ 10.1111/ter.12306.

Pichat, A., Hoareau, G., Callot, J.P., Ringenbach, J.C., 2019. Characterization of oligomiocene evaporite-rich minibasins in the Sivas basin, Turkey. Mar. Petrol. Geol. 110, 587-605.

Pickering, K.T., Hiscott, R.N., 1985. Contained (reflected) turbidity currents from the Middle Ordovician Cloridorme Formation, Quebec, Canada: an alternative to the antidune hypothesis. Sedimentology 32, 373-394. https://doi.org/10.1002/ 9781444304473.ch7.

Plint, A.G., 2014. Mud dispersal across a Cretaceous prodelta: storm-generated, waveenhanced sediment gravity flows inferred from mudstone microtexture and microfacies. Sedimentology 61, 609-647. https://doi.org/10.1111/sed.12068.

Plyusnina, E.E., Ruban, D.A., Conrad, C.P., dos Anjos Zerfass, G. de S., Zerfass, H., 2016. Long-term eustatic cyclicity in the Paleogene: a critical assessment. Proc. Geol. Assoc. 127, 425-434. https://doi.org/10.1016/j.pgeola.2016.03.006.

Poisson, A., Guezou, J.-C., Ozturk, A., Inan, S., Temiz, H., Gürsoy, H., Kavak, K., Özden, S., 1996. Tectonic setting and evolution of the Sivas basin, central anatolia. Turkey. Int. Geol. Rev. 38, 838-853. https://doi.org/10.1080/ 00206819709465366.

Poisson, A., Orszag-sperber, F., Temiz, H., 2010. Stratigraphic and polyphased tectonic evolution of the Sivas basin (central anatolia, Turkey). Darius Annual Report 2010 Proposal No WD 09-11 1-48.

Poisson, A., Orszag-sperber, F., Temiz, H., Vrielynck, B., 2011. Stratigraphic and polyphased tectonic evolution of the Sivas Basin (central anatolia, Turkey). DARIUS Annual Report 2011-Proposal No WD 11-11 1-29.

Posey, H.H., Price, P.E., Kyle, J.R., 1987. Mixed carbon sources for calcite cap rocks of Gulf Coast salt domes. In: Lerche, I., O'Brien, J.J. (Eds.), Dynamical Geology of Salt and Related Structures. Academic Press Inc, pp. 593-630.

Postma, G., Nemec, W., Kleinspehn, K.L., 1988. Large floating clasts in turbidites: a mechanism for their emplacement. Sediment. Geol. 58 (1), 47-61.

Raup, O.B., Hite, R.J., 1992. Lithology of evaporite cycles and cycle boundaries in the upper part of the paradox formation of the hermosa group of pennsylvanian age in the paradox basin. In: Utah and Colorado. U.S. Geol. Surv. Bull, 2000-B 37.

Reed, J., 1994. Probable cretaceous-to-recent rifting in the Gulf of Mexico basin. J. Petrol. Geol. 17, 429-444.

Rego, E., Jovane, L., Hein, J.R., Sant'Anna, L.G., Giorgioni, M., Rodelli, D., Özcan, E., 2018. Mineralogical evidence for warm and dry climatic conditions in the NeoTethys (eastern Turkey) during the middle Eocene. In: Palaeogeogr. Palaeoclimatol. Palaeoecol (in press).

Remacha, E., Fernández, L.P., Maestro, E., 2005. The transition between sheet-like lobe and basin-plain turbidites in the Hecho Basin (South-Central Pyrenees, Spain). J. Sediment. Res. 75 (5), 798-819.

Ribes, C., 2015. Interaction entre la tectonique salifère et la sédimentation dans des minibassins : exemple de l'Oligo- Miocène du bassin de Sivas, Turquie. Ph.D. Thesis. In: Université de Pau et des Pays de l'Adour. France. 
Ribes, C., Kergaravat, C., Bonnel, C., Crumeyrolle, P., Callot, J.P., Poisson, A., Temiz, H., Ringenbach, J.C., 2015. Fluvial sedimentation in a salt-controlled mini-basin: stratal patterns and facies assemblages, Sivas Basin, Turkey. Sedimentology 62, 1513-1545. https://doi.org/10.1111/sed.12195.

Ribes, C., Kergaravat, C., Crumeyrolle, P., Lopez, M., Bonnel, C., Poisson, A., Kavak, K.S. Callot, J.P., Ringenbach, J.C., 2016. Factors controlling stratal pattern and facies distribution of fluvio-lacustrine sedimentation in the Sivas mini-basins, Oligocene (Turkey). Basin Res. 1-26. https://doi.org/10.1111/bre.12171.

Ribes, C., Lopez, M., Kergaravat, C., Crumeyrolle, P., Poisson, André, Callot, J.P., Paquette, J.L., Ringenbach, J.C., 2018. Facies partitioning and stratal pattern in saltcontrolled marine to continental mini-basins: Examples from the Late Oligocene to Early Miocene of the Sivas Basin, Turkey. Mar. Petrol. Geol. 93, 468-496. https:// doi.org/10.1016/j.marpetgeo.2018.03.018.

Ringenbach, J.C., Salel, J.F., Kergaravat, C., Ribes, C., Bonnel, C., Callot, J.-P.P., 2013. Salt tectonics in the Sivas Basin, Turkey: outstanding seismic analogues from outcrops. First Break 31, 93-101. https://doi.org/10.3997/1365-2397.2013016.

Robertson, A., Parlak, O., Ustaömer, T., 2012. Overview of the palaeozoic-neogene evolution of Neotethys in the eastern mediterranean region (southern Turkey, Cyprus, Syria). Petrol. Geosci. 18, 381-404. https://doi.org/10.1144/petgeo2011091.1354-0793/12/.

Rolland, Y., Galoyan, G., Sosson, M., Melkonyan, R., Avagyan, A., 2010. The Armenian ophiolite: insights for jurassic back-arc formation, lower cretaceous hot spot magmatism and upper cretaceous obduction over The south Armenian block. Geol. Soc. Lond.,. Spec. Publ. 340, 353-382.

Rouby, B., 2015. Caractérisation de la séquence de dépôt de la formation Eocène «Bozbel » (Bassin de Sivas, Turquie). Master thesis. Université de Pau et des Pays de l'Adour 1-43. France.

Rouchy, J.M., Sommers, F., 1995. Deep-water resedimentation of anhydrite and gypsum deposits in the middle Miocene (belayim formation) of the Red Sea, Egypt. Sedimentology 42, 267-282. https://doi.org/10.1111/j.1365-3091.1995.tb02102.x.

Rouchy, J., Bernet-Rollande, M.-C., Maurin, A.-F., 1986. Pétrographie descriptive des évaporites, applications sur le terrain en subsurface et au laboratoire. In: TECHNIP (CNRS), vol. 1. Chambre syndicale de la recherche et de la production du pétrole et du gaz naturel - Comité des Techniciens et GRECO 52, Paris, pp. 73-122. Les Séries à Évaporites En Exploration Pétrolière: Methodes Géologiques.

Rouchy, J.M., Taberner, C., Blanc-Valleron, M.M., Sprovieri, R., Russell, M., Pierre, C., Di Stefano, E., Pueyo, J.J., Caruso, A., Dinarès-Turell, J., Gomis-Coll, E., Wolff, G.A., Cespuglio, G., Ditchfield, P., Pestrea, S., Combourieu-Nebout, N., Santisteban, C., Grimalt, J.O., 1998. Sedimentary and diagenetic markers of the restriction in a marine basin: the Lorca Basin (SE Spain) during the Messinian. Sediment. Geol. 121, 23-55. https://doi.org/10.1016/S0037-0738(98)00071-2.

Roveri, M., Manzi, V., Lucchi, F.R., Rogledi, S., 2003. Sedimentary and tectonic evolution of the Vena del Gesso basin (Northern Apennines, Italy): implications for the onset of the Messinian salinity crisis. Bull. Geol. Soc. Am. 115, 387-405. doi:10.1130/00167606(2003)115<0387:SATEOT $>2.0$. CO;2.

Roveri, M., Manzi, V., Lugli, S., Schreiber, C.B., Caruso, A., Rouchy, J.-M., Iaccarino, S. M., Gennari, R., Vitale, F.P., Ricci Lucchi, F., 2006. Clastic vs. Primary precipitated evaporites in the messinian Sicilian basins. Acta Nat 42, 125-199.

Roveri, M., Lugli, S., Manzi, V., Gemmari, R., 2008. Large-scale mass wasting processes in the messinian ciminna basin (northern sicily). Geoacta 7, 81-98. https://doi.org/ 10.1017/CBO9781107415324.004.

Sabino, M., Pierre, F.D., Natalicchio, M., Birgel, D., Gier, S., Peckmann, J., 2020. The response of water column and sedimentary environments to the advent of the
Messinian salinity crisis: insights from an onshore deep-water section (Govone, NW Italy). Geol. Mag. 1-17.

Schlager, W., Bolz, H., 1977. Clastic accumulation of sulphate evaporites in deep water. J. Sediment. Petrol. 47, 600-609.

Schreiber, B.C., Hsü, K.J., 1980. Evaporites. In: Hobson, G.D. (Ed.), Developments in Petroleum Geology. Applied Science Ltd, London, pp. 87-138.

Sinclair, H.D., Tomasso, M., 2002. Depositional evolution of confined turbidite basins. J. Sediment. Res. 72, 451-456. https://doi.org/10.1306/111501720451.

Sirota, I., Enzel, Y., Lensky, N.G., 2017. Temperature seasonality control on modern halite layers in the Dead Sea: in situ observations. Bulletin 129 (9-10), 1181-1194.

Stow, D.A.V., Reading, H.G., Collinson, J.D., 1996. Deep seas. In: Reading, H.G. (Ed.), Sedimentary Environments. Blackwell Publishing Ltd, pp. 395-454.

Tekin, E., 2001. Stratigraphy, geochemistry and depositional environment of the celestine-bearing gypsiferous formations of the Tertiary Ulas-Sivas Basin, EastCentral Anatolia (Turkey). Turkish J. Earth Sci. 10, 35-49.

Testa, G., Lugli, S., 2000. Gypsum-anhydrite transformations in Messinian evaporites of central Tuscany (Italy). Sediment. Geol. 130, 249-268. https://doi.org/10.1016/ S0037-0738(99)00118-9.

Tinterri, R., 2007. The lower Eocene Roda Sandstone (south-central Pyrenees): an example of a flood-dominated river-delta system in a tectonically controlled Basin. Riv. Ital. di Paleontol. e Stratigr 113, 223-255. https://doi.org/10.13130/20394942/5872.

Tinterri, R., 2011. Combined flow sedimentary structures and the genetic link between sigmoidal-and hummocky-cross stratification. Geoacta 10, 43 _85.

Tinterri, R., Muzzi Magalhaes, P., 2011. Synsedimentary structural control on foredeep turbidites: an example from Miocene marnoso-arenacea formation, northern apennines. Italy. Mar. Pet. Geol. 28, 629-657. https://doi.org/10.1016/j. marpetgeo.2010.07.007.

Ugurtas, G., 1975. Geophysical interpretation of part of the tuz gölü basin. Miner. Res. Explor. Inst. Turkey Publ. 85, 38-45.

van den Belt, F.J., de Boer, P.L., 2007. A shallow-basin model for 'Saline Giants' based on isostasy-driven subsidence. In: Nichols, G., Williams, E., Paola, C. (Eds.), Sedimentary Processes, Environments and Basins: A Tribute to Peter Friend. Internal Association of Sedimentologist. Special Publication, pp. 241-252. https://doi.org/ 10.1002/9781444304411.ch11.

Van der Baan, D., 1990. Zechstein reservoirs in The Netherlands. In: Brooks, J. (Ed.), Classic Petroleum Provinces. The Geological Society, London, pp. 379-398.

Vergés, J., Marzo, M., Santaeulària, T, Serra-Kiel, J., Burkbank, D.W., Muñoz, J.A., Giménez-Montsant, J., 1998. Quantified vertical motions and tectonic evolution of the SE Pyrenean foreland basin. Geol. Soc., London, Special Publications 134, 107-134. https://doi.org/10.1144/GSL.SP.1998.134.01.06.

Volozh, Y., Talbot, C., Ismail-Zadeh, A., 2003. Salt structures and hydrocarbons in the Pricaspian basin. Am. Assoc. Petrol. Geol. Bull. 87, 313-334. https://doi.org/ 10.1306/09060200896.

Warren, J., 1990. Evolution of gypsum karst in the kirschberg evaporite member near fredericksburg. Texas. J. Sediment. Res. 60, 721-734.

Warren, J.K., 2016. Evaporites: A Geological Compendium. Springer International Publishing.

Williams-Stroud, S., 1994. The evolution of an inland sea of marine origin to a nonmarine saline lake: the Pennsylvanian Paradox salt. Sedimentol. Geochemistry Mod, Anc. Saline Lakes,. SEPM (Soc. Sediment. Geol.) Spec. Publ. 50, 293-306.

Yilmaz, A., Yilmaz, H., 2006. Characteristic features and structural evolution of a post collisional basin: the Sivas Basin, Central Anatolia, Turkey. J. Asian Earth Sci. 27, 164-176. https://doi.org/10.1016/j.jseaes.2005.02.006. 